\title{
LA CONFIGURACIÓN DE LA IMPRUDENCIA COMO «GRAVE»Y «MENOS GRAVE» EN LOS DELITOS DE HOMICIDIO Y LESIONES DE LOS ARTS. 142 Y 152 CP TRAS LA REFORMA DEL CÓDIGO POR LA LO 1/2015: ESPECIAL REFERENCIA A SU CONCEPTUALIZACIÓN EN EL ÁMBITO VIAL
}

\author{
Luis Rodríguez Moro \\ Universidad de Cádiz
}

SUMARIO: 1. Introducción. 2. El cambio en la configuración de la imprudencia introducido por la LO $1 / 2015$, de 30 de marzo, en los arts. 142 y 152 CP. 3. ¿Es la imprudencia menos grave una nueva categoría de imprudencia? Preámbulo de la LO 1/2015. 3.1. ¿Qué dice el Preámbulo de la LO 1/2015? 3.2. Otros argumentos en la línea de lo que dice la LO 1/2015. 4. Estado de la cuestión en la doctrina y la jurisprudencia. 5. Análisis del Dictamen 2/2016 del Fiscal de Sala Coordinador de Seguridad Vial: conceptualización de la imprudencia en el ámbito del tráfico rodado. 5.1. Concepto de imprudencia «menos grave» 5.2. Criterios de valoración de la gravedad de la imprudencia en abstracto. 5.3. Criterios de valoración de la gravedad de la imprudencia en concreto. 6. Conclusiones. 7. Bibliografía

\section{Introducción}

No cabe duda de que las reformas realizadas en el Código penal por la reciente LO 1/2015, de 30 de marzo, son de enorme trascendencia. Tanto las relativas a la Parte General del Derecho penal como las relativas a los delitos en particular. Entre las primeras, junto a la incorporación de la pena de prisión permanente revisable, una profunda revisión de la suspensión de la ejecución de las penas privativas de libertad y la eliminación formal de las "faltas» del Código - aunque algunas se castiguen ahora como delitos-, destaca la nueva regulación otorgada a la imprudencia delictiva. Curiosamente, este último cambio de Parte General se refleja de modo expreso en la Parte Especial del Código, en los dos 
únicos delitos en los que se castiga una de las dos modalidades de imprudencia, que es la que precisamente ha variado, al menos, de adjetivación. Si con anterioridad a la reforma los delitos de homicidio y lesiones sancionaban, en los arts. 142 y $152 \mathrm{CP}$, los cometidos por imprudencia grave y por imprudencia leve, ahora esta segunda categoría desaparece para dejar hueco a la llamada imprudencia menos grave. El presente trabajo tiene como fin analizar esta modificación, conceptualizar la nueva categoría de imprudencia y delimitar su espacio de acción con respecto a la grave, que sigue prevista en el Código, y la leve que expresamente se reconduce al ámbito civil, tal y como indica el Preámbulo de ley reformadora citada supra.

Resulta obligado apuntar que este estudio se centrará concretamente en el análisis de la nueva graduación de la imprudencia, esto es, en el contenido que ha sido objeto de modificación. Ello sin perjuicio de que en su desarrollo sea necesario hacer alguna mención a cuestiones generales sobre la naturaleza, fundamento y elementos de la imprudencia como parte del tipo de injusto. Así, por ejemplo, sobre la infracción del deber objetivo de cuidado, qué es lo que conforma o perfila dicho deber (normas que regulan ciertas actividades peligrosas, la - lex artis - que rige el ejercicio de algunas profesiones o el principio de confianza), el resultado que ha de estar unido en relación de causalidad con aquella infracción, la imputación objetiva, previsibilidad y evitabilidad de dicho resultado, o cuestiones subjetivas como el elemento negativo de no querer cometer el hecho resultante o la consciencia del deber de cuidado. Son cuestiones a las que en alguna medida habrá que referirse para conocer qué es la imprudencia y poder así establecer con más acierto y precisión las diferencias entre las distintas categorías de imprudencia. Pero son cuestiones a las que no se les podrá dar el profundo tratamiento que merecen por razones de espacio ${ }^{1}$.

También resulta obligado apuntar que el presente trabajo, aunque intenta precisar el concepto de esta nueva categoría de imprudencia en términos globales, esto es, con respecto a cualquier caso de homicidio o lesiones en que pueda producirse — para lo que se tendrán en cuenta las opiniones doctrinales emitidas hasta la fecha-, se centra con más detalle en el ámbito del tráfico vial, que es, junto con el ámbito médico, en el que con más frecuencia se dan los delitos imprudentes ${ }^{2}$. Por ello,

1 Vid., en términos generales, sobre la imprudencia delictiva, las monografías de CoRCoy BIDAsolo, M., El delito imprudente. Criterios de imputación del resultado. PPU, Barcelona, 1989, pássim; GIL GIL, A., El delito imprudente. Fundamentos para la determinación de lo injusto imprudente en los delitos activos de resultado. Atelier, Barcelona, 2007, pássim; HaVa García, E., La imprudencia inconsciente. Comares, Granada, 2002, pássim; y PéreZ Del Valle, C., La imprudencia en el Derecho penal. El tipo subjetivo del delito imprudente. Atelier, Barcelona, 2012, pássim.

2 Por todos, De Vicente Martínez, R., «La reforma de 2015 y su incidencia en los accidentes de circulación», en Revista Aranzadi Doctrinal. N. ${ }^{\circ}$ 5, Mayo 2017, p. 48. 
se efectuará un análisis pormenorizado del Dictamen 2/2016 del Fiscal de Sala Coordinador de Seguridad Vial que precisamente tiene como objeto estudiar esta reforma de la imprudencia, conceptualizar la menos grave y recoger una serie de criterios de valoración de la gravedad de la imprudencia tanto desde una perspectiva general como más concreta en el ámbito de la seguridad vial.

Sin duda alguna, constituye este un tema de enorme importancia, toda vez que de la determinación de una u otra clase de imprudencia se hace depender el reenvío del enjuiciamiento de un comportamiento a la vía civil o a la penal y, en caso de optar por la segunda, que se apliquen sanciones bien distintas en función de la graduación que se haga. Y ello sin olvidar que el análisis se especializa en un ámbito, el de la seguridad vial, caracterizado por generar de los más elevados índices de fallecimiento y lesión en todo el mundo, cuya causa lo es con frecuencia el desarrollo de una conducción negligente que merece recibir una consecuencia jurídica adecuada y proporcionada a sus tan variables circunstancias.

\section{El cambio en la configuración de la imprudencia introducido por la LO 1/2015, de 30 de marzo, en los arts. 142 y $152 \mathrm{CP}$}

$\mathrm{El}$ art. $142 \mathrm{CP}$ alberga en dos apartados el delito de homicidio imprudente, mientras que el art. $152 \mathrm{CP}$, de estructura similar, recoge, también en dos apartados, el delito de lesiones cometidas por imprudencia. Esa subdivisión de los preceptos en dos apartados resulta de interés a los efectos de este estudio, pues en los primeros apartados se recogen tales delitos cuando son cometidos por imprudencia grave y en los segundos cuando lo son por imprudencia menos grave. Estas son las dos clases de imprudencia reconocidas expresamente en el Código Penal ${ }^{3}$, las cuales necesitan ser objeto de delimitación, toda vez que las consecuencias jurídicas que van a implicar son bien distintas.

Con respecto a la imprudencia grave, el art. 142. l CP señala que el "que por imprudencia grave causare la muerte de otro, será castigado, como reo de homicidio imprudente, con la pena de prisión de 1 a 4 años». Con respecto al ámbito del tráfico rodado, el precepto añade que si el homicidio imprudente se hubiera cometido «utilizando un vehículo a motor o un ciclomotor, se impondrá asimismo la pena de

3 Para la doctrina resulta relevante también, aunque no venga recogida como tal en el Código, la clasificación de la imprudencia como consciente e inconsciente, a los efectos de poder diferenciar la primera de ellas del dolo eventual. Por todos, MIR PUIG, S., Derecho penal Parte General (10. a edición). Reppertor, Barcelona, 2016, p. 294. 
privación del derecho a conducir vehículos a motor y ciclomotores de 1 a 6 años». Por su parte, el art. 152. $1 \mathrm{CP}$ castiga la comisión de las lesiones dolosas de los arts. 147.1, 149 y $150 \mathrm{CP}$ cuando son cometidas con este tipo de imprudencia grave 4 . Concretamente indica que «el que por imprudencia grave causare alguna de las lesiones previstas en los artículos anteriores será castigado, en atención al riesgo creado y el resultado producido: $1 .{ }^{\circ}$ Con la pena de prisión de 3 a 6 meses o multa de 6 a 18 meses, si se tratare de las lesiones del apartado 1 del art. 147; 2. ${ }^{\circ}$ Con la pena de prisión de 1 a 3 años, si se tratare de las lesiones del art. 149; y 3. ${ }^{\circ}$ Con la pena de prisión de 6 meses a 2 años, si se tratare de las lesiones del art. 150». En el siguiente párrafo, se especifica con respecto al ámbito del tráfico rodado que «si los hechos se hubieran cometido utilizando un vehículo a motor o un ciclomotor, se impondrá asimismo la pena de privación del derecho a conducir vehículos a motor y ciclomotores de 1 a 4 años» ${ }^{5}$. Por la duración de las penas, ambos delitos son delitos menos graves ${ }^{6}$.

${ }^{4} \mathrm{El}$ art. 147.1 CP recoge el tipo básico de lesiones dolosas en el que se castiga al que, por cualquier medio o procedimiento, causare a otro una lesión que menoscabe su integridad corporal o su salud física o mental, siempre que la lesión requiera objetivamente para su sanidad, además de una primera asistencia facultativa, tratamiento médico o quirúrgico. El art. $149 \mathrm{CP}$ recoge un tipo agravado en el que se castiga al que causara a otro, por cualquier medio o procedimiento, la pérdida o la inutilidad de un órgano o miembro principal, o de un sentido, la impotencia, la esterilidad, una grave deformidad, o una grave enfermedad somática o psíquica, así como al que causara a otro una mutilación genital en cualquiera de sus manifestaciones. Por último, el art. $150 \mathrm{CP}$ recoge también un tipo agravado, aunque con una pena más reducida que el anterior, en el que se castiga al que causare a otro la pérdida o la inutilidad de un órgano o miembro no principal, o la deformidad.

${ }^{5}$ La pena de privación del derecho de conducir se vincula estrechamente en estos delitos con el ilícito cometido, ya que supone la inhabilitación para el ejercicio de un derecho que se ha ejercido de una forma imprudente y que, además, ha ocasionado un resultado de muerte o lesiones. Pero la pena no se prevé para los delitos dolosos de homicidio o de lesión cometidos con vehículo a motor o ciclomotor, pues en ellos el vehículo no es más que un mero instrumento del delito utilizado de modo intencional para matar o lesionar, lo que estaría al margen de la seguridad vial. Sin embargo, ToRRES FERNÁNDEZ, M. ${ }^{\mathrm{a}}$. E., «Reflexiones sobre algunos efectos administrativos del llamado "carnet por puntos» en las consecuencias penales de los delitos contra la seguridad vial», en Morillas Cueva, L. (Coord.), Delincuencia en materia de tráfico y seguridad vial (aspectos penales, civiles y procesales). Dykinson, Madrid, 2007, p. 101, cree con acierto que en estos casos en los que se conduce con la intención de causar al menos una lesión a alguien es más que posible ocasionar un riesgo para la seguridad vial y para la vida o integridad de otras personas, razón por la que considera censurable la ausencia de esta pena en ellos.

6 Cabe indicar que se ha presentado en el Congreso de los Diputados la Proposición de Ley Orgánica, de 30 de junio de 2017, de reforma del Código Penal en materia de imprudencia en la conducción de vehículos a motor o ciclomotor y sanción del abandono del lugar del accidente, que pretende dar respuesta a la demanda social surgida tras el incremento de accidentes en los que resultan afectados peatones y ciclistas por imprudencia en la conducción vial. El texto propuesto, en relación a la imprudencia grave, prevé el añadido de una misma referencia en los párrafos segundos de los arts. 142.1 (homicidio) y 152.1 (lesiones) CP, después de la mención a la imposición de la pena privativa del de- 
Por lo que respecta a la imprudencia menos grave, el apartado 2 del art. $142 \mathrm{CP}$ señala que «el que por imprudencia menos grave causare la muerte de otro, será castigado con la pena de multa de 3 meses a 18 meses» y que "si el homicidio se hubiera cometido utilizando un vehiculo a motor o un ciclomotor, se podrá imponer también (por tanto, en este caso de forma potestativa) la pena de privación del derecho a conducir vehículos a motor y ciclomotores de 3 a 18 meses». Con respecto, al delito de lesiones, el apartado 2 del art. $152 \mathrm{CP}$ señala que «el que por imprudencia menos grave causare alguna de las lesiones a que se refieren los arts. 149 y 150 será castigado con una pena de multa de 3 meses a 12 meses», y que "si los hechos se hubieran cometido utilizando un vehículo a motor o un ciclomotor, se podrá imponer también (potestativa) la pena de privación del derecho a conducir vehículos a motor y ciclomotores de tres meses a un año». Por la duración de las penas, ambos delitos son delitos leves.

Fíjese que en los delitos de lesiones imprudentes, que se caracterizan por un especial desvalor de acción cifrado en el actuar «imprudente», se le da vital importancia al desvalor de resultado, pues de este deriva que puedan ser sancionados o no. Así, para que las conductas de lesiones sean delictivas, las cometidas con imprudencia grave tienen que ocasionar los resultados lesivos de los arts. 147.1, 149 o $150 \mathrm{CP}$, y las cometidas con imprudencia menos grave únicamente serán delictivas si se producen las lesiones agravadas de los arts. 149 y $150 \mathrm{CP}^{7}$.

recho de conducir. Para ambos delitos se especifica que «a los efectos de este apartado, se reputará en todo caso como imprudencia grave la conducción en la que concurra alguna de las circunstancias previstas en el artículo 379 del Código Penal», esto es, la conducción a velocidad excesiva o influenciada por el consumo de alcohol o drogas o por encima de las tasas indicadas en el citado precepto. Así mismo, ambos delitos de los arts. 142 y $152 \mathrm{CP}$ se ven provistos de un novedoso apartado 3 que vendría a señalar que «en estas infracciones el Juez o Tribunal podrá imponer, motivadamente, la pena superior en uno o dos grados, en la extensión que estime conveniente, si el hecho revistiere notoria gravedad y hubiere afectado a la integridad física de una pluralidad de personas con un resultado constitutivo de delito». El contenido reformador de la Propuesta de Ley prevé también la eliminación de la cláusula concursal del art. $382 \mathrm{CP}$, aplicable a los delitos contra la seguridad vial, que implicaría el empleo de las más gravosas reglas generales de concurso de delitos. Y también la incorporación de un nuevo delito de fuga en el ámbito vial. En él se castiga «al conductor implicado en un accidente de tráfico que abandone el lugar de los hechos». En vez de a un conductor «implicado» debería haberse referido al que «haya participado» $u$ "ocasionado» el accidente (las víctimas también son «implicados»). Y resultan discutibles, además, las penas previstas, porque se prevé la aplicación de una pena menor (prisión de 3 a 6 meses de prisión o multa de 12 a 24 meses) «si se abandonare a una persona que hubiera sufrido lesiones constitutivas de delito», que si el abandonado fuere de «una persona que falleciera a consecuencia del accidente» (prisión de 6 meses a 4 años de prisión), pues el herido abandonado es alguien que aún puede salvar su vida, lo que quizá haga más reprochable su abandono. Y ello sin olvidar que el inculpado siempre puede alegar haber creído abandonar a alguien cuyo abandono recibirá menos pena.

7 Vid. Doval PaIS, A., «Homicidios y lesiones por imprudencia: evolución, nuevo régimen y límites», en La ley penal: revista de derecho penal, procesal y penitenciario, n. ${ }^{\circ} 119$, 
Pues bien, si se pone especial atención a la evolución que ha tenido el tratamiento de la imprudencia en el Código y a los recientes cambios que esta ha sufrido, pudiera parecer que las figuras delictivas de imprudencia menos grave de los arts. 142.2 y 152.2 CP constituyen delitos de nueva creación, ya que esta categoría de imprudencia resulta nueva, desconocida hasta la fecha ${ }^{8}$, al menos terminológicamente, para el ordenamiento jurídico-penal. Fue introducida por la LO 1/2015, de 30 de marzo, de reforma del Código penal, aunque cabe indicar que ello ha sido consecuencia de la voluntad general de la citada reforma de eliminar las faltas del ordenamiento penal. Al margen de los motivos de este histórico cambio en la regulación penal, explicitados en el Preámbulo de la Ley de 2015², y del cumplimiento o no de ellos por la nueva regulación ${ }^{10}$ — que se esca-

2016, p. 2; HaVA GaRcía, E., «Responsabilidad penal por imprudencia en la celebración de grande eventos: un análisis de algunas cuestiones problemáticas en el caso Madrid Arena», en Indret, Barcelona, abril 2017, p. 30, nota 87; LANZARote MARTíneZ, P.A., «El nuevo delito de imprudencia menos grave en la reforma del Código penal», Diario La Ley, n. ${ }^{\circ} 8600,8$ septiembre 2015, p. 1737; y Medrano ARANGUREN, A., Accidentes de tráfico: vía penal o vía civil», en CEFLegal: revista práctica de Derecho. Comentarios y casos prácticos. N. ${ }^{\circ}$ 190, 2016, p. 175. Vid., también, las SSAP de Burgos 34/2017, de 30 de enero, de Santander 229/2016, de 26 de abril; de Burgos 379/2015, de 14 de octubre; y de A Coruña $274 / 2015$, de 31 de julio, que no aprecian el delito por que no se producen los resultados lesivos requeridos a la imprudencia de que se trate. También, la STS 85/2017, de 11 de diciembre (Caso «Madrid Arena»), que aplica retroactivamente la normativa de la reforma de 2015, pues el imputado que actuó con imprudencia menos grave cometió las lesiones del art. 147, despenalizadas con la reforma. Y los AAP de Ciudad Real 204/2017, de 12 de junio; de Las Palmas 198/2017, de 13 de marzo, de Soria 162/2016, de 19 de diciembre, y de Alicante 619/2016, de 15 de septiembre.

8 Cfr. Doval PaIS, A., «Homicidios», cit., p. 3; y la STS 85/2017, de 11 de diciembre.

9 El cambio había sido requerido por la FGE y por el CGPJ, y venía avalado por el hecho de que se había producido en otros países de nuestro entorno como Austria, Suiza, Alemania o Portugal. El Preámbulo se refiere, desde una perspectiva material, a que con el cambio se pretende reservar el Derecho Penal para casos de especial gravedad - lo que vendría a ser una exigencia del principio de intervención mínima-, y a facilitar una disminución de la elevada litigiosidad de los juzgados penales por asuntos menores que podrían encontrar mejor y más rápida respuesta a través del sistema de sanciones administrativas y civiles. Y, también, que así se conseguiría diferenciar mejor las respuestas punitivas del Derecho Penal y el Derecho Administrativo sancionador, pues a veces esta última ofrecía una respuesta más contundente.

10 A favor de la supresión de las faltas, Díez Ripollés, J.L., «Sucintas observaciones sobre algunas decisiones del Anteproyecto de reforma del Código penal de 2012», en ÁtvAREZ GARCíA, F.J. (Dir.), Estudio crítico sobre el anteproyecto de reforma penal de 2012. Tirant lo Blanch, Valencia, 2013, p. 51; Magro Servet, V., «La derogación de las faltas del Código penal: nuevas vías para luchar contra la delincuencia menor», en La Ley, 2009/4, pp. 18641866; y SANTOS MARTíneZ, A.M., «La «desjudicialización» de las faltas», en La Ley, 2011/4, pp. 1389-1391; aunque ninguno concuerde con la forma en cómo se ha efectuado. Alguna doctrina critica la fórmula seguida tras analizar las razones explicitadas en el Preámbulo y las reales de la eliminación de las faltas o de la conversión de estas en delitos leves. Vid., sobre ello, Cugat Mauri, M., "Consecuencias penales de la supresión del Libro III», en Quintero Olivares, G. (Dir.), Comentario a la reforma penal de 2015. Thomson Aranzadi, Navarra, 2015, pp. 233-234 y 227-228; FARALDO CABANA, P., «La despenalización de las faltas: entre la agravación de las penas y el aumento de la represión administrativa», en 
pan del objeto de estudio-, lo cierto es que aunque formalmente hayan desaparecido las faltas, y el Libro III CP que las albergaba, ello no quiere decir que hayan desaparecido del Código todos los comportamientos que dichas faltas recogían, lo que, como se verá, resulta una cuestión a tratar en este estudio. De hecho, según la doctrina, son menos de un tercio de las faltas las que realmente desaparecen ${ }^{11}$, pues las restantes reaparecen en el Código, como delitos leves (autónomos o atenuados de otros delitos preexistentes), como nuevos delitos menos graves, o se integran en los supuestos de hecho de delitos menos graves ya existentes (lo que implica, en la casi totalidad de los casos, una mayor dureza de su castigo) ${ }^{12}$.

Por tanto, se insiste, cabe reflexionar sobre si los citados nuevos delitos de homicidio y lesiones por imprudencia menos grave son verdaderamente figuras de nueva creación o son solo una transformación de las derogadas faltas de homicidio y lesiones cometidas por imprudencia leve del antiguo art. $621 \mathrm{CP}$, que vendrían a «reaparecer» o a ocupar este «nuevo lugar» en las correlativas figuras de homicidio y lesiones cometidas por imprudencia menos grave. Por este mismo motivo, también se duda de si la imprudencia menos grave es o no una nueva categoría de imprudencia.

El derogado art. $621 \mathrm{CP}$ castigaba en su apartado 2 a los que por imprudencia leve causaren la muerte de otra persona (con la pena de multa de 1 a 2 meses), y en su apartado 3 a los que por imprudencia leve causaran (cualquiera) lesión constitutiva de delito (con pena de multa de 10 a 30 días), supuestos para los que se abría la posibilidad de imponer la pena de privación del derecho a conducir vehículos a motor y ciclomotores (de 3 meses a 1 año) si el hecho se cometiera con vehículo a motor o ciclomotor.

Comparando las regulaciones vigente y derogada se pueden apreciar más cambios en estas figuras, aparte de su nueva denominación como delitos de «imprudencia menos grave», y de su catalogación como delitos leves y ya no como faltas. En primer lugar, la pena de multa de los

Indret. Revista para el análisis del Derecho, n. ${ }^{\circ} 3$, Barcelona, 2014, pp. 18 y 24-25; FERnÁNDez Hernández, A. / Olloquiegui Sucunza, I., "Notas críticas sobre la conversión de las faltas en delitos en el Anteproyecto de Reforma de 2012», en Álvarez GaRcía, F.J. (Dir.), Estudio crítico sobre el anteproyecto de reforma penal de 2012. Tirant lo Blanch, Valencia, 2013, pp. 69-70; y Rando CASERMeiro, P., La distinción entre el Derecho penal y el Derecho administrativo sancionador. Un análisis de política jurídica. Tirant lo Blanch, Valencia, 2010, p. 523.

11 Así, Fernández Hernández, A., "Supresión de las faltas y creación de los delitos leves», en González Cussac, J.L. (Dir.), Comentarios a la reforma del Código penal de 2015 (2. ${ }^{a}$ edición). Tirant lo Blanch, Valencia, 2015, p. 52, que señala que de las 44 faltas que existían antes de la reforma solo 17 quedan definitivamente fuera del texto punitivo; o De Vicente Martínez, R., «La reforma», cit., p. 42, cuando señala que más del $60 \%$ de las faltas se han convertido en delitos leves.

$12 \mathrm{Vid}$., sobre qué faltas se eliminan, se transforman en delitos o en infracciones no penales, FARALDo CABANA, P., «La despenalización», cit., pp. 4-7, que señala que estamos más ante un proceso de descriminalización que de despenalización; y FERnánDEz HeRnández, A., «Supresión», cit., pp. 45-47. 
delitos de homicidio y lesiones imprudentes de los arts. 142.2 y 152.2 $\mathrm{CP}$ es mucho más elevada que la de las correlativas faltas del derogado art. 621.2 y $3 \mathrm{CP}$, respectivamente. Incluso se amplía el límite superior de la pena de privación del derecho de conducir en el delito de homicidio cometido por imprudencia menos grave, que pasa de 12 a 18 meses $^{13}$. También, en la regulación anterior se castigaba en el art. 621.3 CP la realización de cualquier lesión constitutiva de delito cometida por imprudencia leve, mientras que el nuevo tipo de lesiones por imprudencia menos grave del art. 152.2 CP solo castiga la realización de las lesiones más graves de los arts. 149 y $150 \mathrm{CP}$ (se excluyen las lesiones del art. 147 $\mathrm{CP})^{14}$. Lo que no ha cambiado es la tipología de penas aplicables a los nuevos delitos de los arts. 142.2 y $152.2 \mathrm{CP}$, que siguen siendo la multa y la privación del permiso de conducir vehículos a motor (aunque con distintas duraciones), y que la aplicación de la segunda pena sigua siendo potestativa. También, que el castigo de la imprudencia menos grave solo se prevé para estas dos tipologías delictivas de homicidio y lesiones.

Con este nuevo escenario legislativo, la cuestión a determinar es si esta nueva imprudencia menos grave constituye verdaderamente una nueva categoría de imprudencia - por tanto, dentro de una distinta clasificación de la imprudencia en atención a su gravedad-, el cual ha de ser precisado para diferenciarlo de las otras categorías de imprudencia, o si, por el contrario, solo constituye una nueva forma de llamar a la

13 La citada supra Proposición de Ley Orgánica, de 30 de junio 2017, de reforma del Código Penal en materia de imprudencia en la conducción de vehículos a motor o ciclomotor y sanción del abandono del lugar del accidente, también prevé una elevación de las penas de la imprudencia, de la grave y de la menos grave y tanto en el homicidio como en las lesiones imprudentes. En los apartados 3 de los arts. 142 y 152 se prevé que «en estas infracciones el Juez o Tribunal podrá imponer, motivadamente, la pena superior en uno o dos grados, en la extensión que estime conveniente, si el hecho revistiere notoria gravedad y hubiere afectado a la integridad física de una pluralidad de personas con un resultado constitutivo de delito». Esta disposición potestativa le podría otorgar al juez un marco de penalidad gigante. En el delito de homicidio por imprudencia grave, por ejemplo, sería de 1 a 9 años de prisión, y en el homicidio por imprudencia menos grave, de 3 meses a 40 meses y 15 días de multa. Constituye una agravación censurable ya que vulnera los principios de seguridad jurídica e igualdad, pues muy probablemente acabe derivando en la presencia de pronunciamientos muy dispares sobre casos iguales en diferentes provincias del país.

14 Recuerda FernÁNDEZ Hernández, A., «Supresión», cit., p. 68, que en la actualidad también han desaparecido del Código penal las lesiones cometidas por imprudencia grave que requerían tratamiento médico o quirúrgico pero «de menor gravedad» del art. 147.2 $\mathrm{CP}$, sancionadas antes como falta en el art. $621.1 \mathrm{CP}$, y que ahora no están recogidos en el nuevo art. 152.1 CP, en el que por imprudencia grave solo se castigan las lesiones del tipo básico del art. 147.1 CP y las de los tipos agravados de los arts. 149 y $150 \mathrm{CP}$. No obstante, esta afirmación no es correcta. Es cierto que formalmente ya no se castigan las lesiones del art. 147.2 CP cometidas por imprudencia grave, pero el contenido de este artículo ha variado, ya que en la actualidad recoge el castigo de las lesiones que no requieren para su curación tratamiento médico o quirúrgico, esto es, las lesiones que antes eran constitutivas de falta, y las lesiones que si lo requieren «de menor (o cualquier) gravedad», se castigan ahora, todas ellas, en el art. 147.1 CP. 
antigua imprudencia leve - producto de la derogación de las faltas y la reubicación de algunas de ellas entre los delitos-, lo que implica que siga teniendo el mismo contenido y extensión.

\section{3. ¿Es la imprudencia menos grave una nueva categoría de imprudencia? Preámbulo de la LO 1/2015}

Como se acaba de indicar, el Código Penal recoge expresamente dos categorías de imprudencia: la grave y la menos grave, que en ninguna parte de su articulado define. El Preámbulo de la LO 1/2015 que introdujo la imprudencia menos grave tampoco lo hace. Y esta situación de «indefinición» no es nueva, pues antes de 2015 el Código tampoco establecía expresamente ni la conceptualización ni la diferenciación entre las viejas categorías de imprudencia grave y leve. Ante este vacío, fueron la doctrina y la jurisprudencia las que lo establecieron.

Con carácter previo, habría que señalar de un modo genérico, y sin entrar en detalle sobre todos sus elementos, que el comportamiento imprudente es aquel con el que no se quiere realizar el resultado típico - no es buscado por su autor-, pero que finalmente se produce por - $\mathrm{y}$ es objetivamente imputable a- la infracción de un deber de cuidado, esto es, por la inobservancia de un cuidado objetivamente debido para el desarrollo de una actividad social determinada - fruto de una impericia, un descuido o un obrar arriesgado- que evidencia que el resultado de aquel hecho típico fuera, o al menos debiera ser, previsible ex ante, y que se hubiera podido evitar actuando conforme a la norma de cuidado ${ }^{15}$.

A grandes rasgos, la diferencia entre aquellas dos clases de imprudencia grave y leve reside en el desvalor de acción, esto es, en la gravedad

15 Vid., sobre el concepto y contenido del delito imprudente, EstEBAN, R., «El delito imprudente», en AA.VV. La imprudencia. Cuadernos de Derecho judicial. CGPJ, Madrid, 2006, pp. 54-55; GIL GIL, A., "Artículo 12», en Gómez Tomillo, M., Comentarios prácticos al Código penal. Tomo I. Parte General. Artículos 1-137. Aranzadi, Navarra, 2015, pp. 152-162; Mir Puig, S., Derecho penal, cit., pp. 292-293; Quintero Olivares, G., Parte General del Derecho Penal. Adaptada al programa de ingreso en las carreras judicial y fiscal. Aranzadi, Navarra, 2015, pp. 433-440, que define el delito imprudente como «la ejecución del tipo objetivo de un delito doloso, a causa de haber infringido un deber de prudencia o de cuidado, sea por ignorar la concurrencia de ese deber, y con ello, hasta la misma situación de riesgo, o porque, aun conociéndola, el autor creyó que un resultado previsible no habría de producirse, todo ello realizando una acción que objetivamente puede ser imputada al autor»; RAmos TAPIA, I., «Delito de acción: la tipicidad (III)», en Zugaldía EsPinAR, J.M., Lecciones de Derecho Penal. Parte General (3. ${ }^{\mathrm{a}}$ edición). Tirant lo Blanch, Valencia, 2016 (3. ${ }^{\mathrm{a}}$ ed.), pp. 126-127; y Roxin, C., Derecho penal. Parte General. Tomo I. Fundamentos. La estructura de la teoría del delito. Civitas, 2006, pp. 999-1001. Como señala alguna de esta doctrina, de esta definición se aprecia un aspecto interno y externo en el deber de cuidado: el interno es el deber de advertir el peligro y el externo es el deber de comportarse conforme a las normas de cuidado previamente advertidas. 
objetiva del comportamiento infractor de la norma de cuidado o, dicho de otro modo, la gravedad objetiva del riesgo no permitido generado por dicho comportamiento ${ }^{16}$. Ello se medirá esencialmente con base en la importancia de la norma de cuidado infringida, lo que tiene que ver con la valoración social del riesgo, según se trate de ámbitos que admiten ciertos grados de riesgo permitido o no ${ }^{17}$. Y también con el grado de probabilidad objetiva del resultado típico, el grado de previsibilidad individual de dicho resultado ${ }^{18}$, la mayor o menor importancia del bien jurídico afectado (a igual probabilidad de lesión, mayor gravedad si se refiere a un bien jurídico más importante $)^{19}$ y la utilidad social derivada de la realización del riesgo según las circunstancias concretas que se den. Así mismo, el

16 Vid. Cerezo Mir, J., Curso de Derecho penal español. Parte General. Tomo II. Teoría jurídica del delito (6. ${ }^{\mathrm{a}}$ edición). Tecnos, Madrid, 2005, pp. 174-175; Corcoy BiDAsoLO, M., El delito, cit., pp. 367-368; Daunis RodríGuez, A., «La imprudencia», cit., pp. 2-ss.; Doval Pais, A., «Homicidios», cit., p. 10; Hava García, E., La imprudencia, cit., pp. 179-

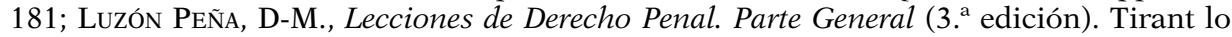
Blanch, Valencia, 2016, p. 296; Muñoz Conde, F. / García ARÁn, M., Derecho, cit., p. 308; Orts Berenguer, E. / González Cussac, J.L., Compendio de Derecho Penal. Parte General (6. ${ }^{a}$ edición). Tirant lo Blanch, Valencia, 2016, p. 343; Quintero Olivares, G., Parte General, cit., p. 444; Romeo CASABONa, C.M., «El homicidio y sus formas», en Romeo CASABONa, C.M., Derecho Penal. Parte especial. Conforme a las Leyes Orgánicas 1 y 2/2015, de 30 de marzo. Granada 2016, p. 18; y TerRadillos Basoco, J.M. ${ }^{a}$., "Homicidio y sus formas», en Terradillos Basoco, J.M. ${ }^{\text {a }}$ (Coord.), Lecciones y materiales para el estudio del Derecho Pe-

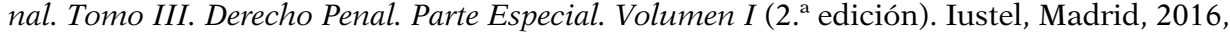
p. 19. Por el contrario, Pérez Del VAlle, C., La imprudencia, cit., pp. 183-184, sigue una interpretación subjetiva de la gravedad de la imprudencia, al suponer una determinación cuantitativa de la evitabilidad individual. Según él, «existe la imprudencia grave cuando, para el autor, la adquisición del conocimiento concreto de los factores de riesgo es fácilmente accesible y la orientación... de su comportamiento como inocuo para los intereses en riesgo resulta viable».

17 Cfr. MiR Puig, S., Derecho penal, cit., p. 295, quien señala que «la valoración social del riesgo depende de si se produce en ámbitos en que se admiten determinados grados de riesgo permitido: un grado de peligrosidad que podría ser grave fuera de uno de estos ámbitos puede ser menos grave dentro de ellos»; y Roxin, C., Derecho, cit., p. 1027.

18 Hava García, E., La imprudencia, cit., pp. 187-189, en referencia a estos dos criterios como los esenciales para efectuar la graduación de la gravedad de la imprudencia.

19 Corcoy Bidasolo, M., El delito, cit., pp. 367; Ramos TAPIA, I., «Delito», cit., p. 129; Roxin, C., Derecho, cit., p. 1027; y Terradillos Basoco, J.M. ${ }^{\text {a., } ~ « H o m i c i d i o », ~ c i t ., ~ p . ~ 19 . ~ V i d . ~}$ las SSTS 26/2010, de 25 de enero, 168/2008, de 29 de abril, 649/2002, de 12 de abril, y 2235/2001, de 30 de noviembre. También, HaVA García, E., La imprudencia, cit., pp. 184-186, aunque matizando que este criterio ha de relativizarse y comprobarse en el caso concreto, pues no hay que olvidar que la importancia del bien jurídico ya es tenida en cuenta para sancionar precisamente los comportamientos culposos. Además, no hay que perder de vista la cuestión a analizar, esto es, la gravedad. Habrá que evitar, pues, la tendencia de elevar a la categoría de «graves» todas las conductas descuidadas que pongan en peligro o lesionen bienes fundamentales, con base en dicho único criterio. En este sentido, también, DauNIS RodRíGUEZ, A., «La imprudencia», cit., pp. 23-24, cuando dice que no hay que confundir el valor de los bienes jurídicos con el riesgo potencial del comportamiento imprudente. Es lógico que sea considerado más grave conducir a $180 \mathrm{~km} / \mathrm{h}$ cerca de un centro escolar que hacerlo en una autopista por la noche, aunque, más que al bien jurídico protegido, ello se debe a la mayor potencialidad lesiva del comportamiento. 
objetivo deber de cuidado ha de individualizarse (subjetivarse) en un ulterior momento conforme a los conocimientos, habilidades y capacidades especiales del autor con relación al contenido del concreto riesgo (pues lo prudente para uno puede no serlo para otro o, dicho de otro modo, una misma infracción puede ser considerada de mayor gravedad si es cometida por un sujeto con cualidades o habilidades especiales) ${ }^{20}$.

Aunque no hay unanimidad al respecto, en sede jurisprudencial, la imprudencia grave suele identificarse con aquella con alta previsibilidad de lesión por suponer la omisión de todas las preocupaciones o medidas de cuidado o control debido o, al menos, las más elementales, que son exigidas a todas las personas, incluso a los menos diligentes, en el desarrollo de una actividad. La imprudencia leve se identificaría con aquella que se aprecia en la infracción de una norma de cuidado debido no elemental o inexcusable, o en una infracción leve de una norma de cuidado elemental, siempre que sea una actividad no muy peligrosa o una actividad peligrosa respecto de la que se adoptan algunas medidas de control aunque insuficientes ${ }^{21}$. Y ello sin obviar que el comportamiento imprudente de la víctima puede, en

20 Vid., sobre esta cuestión, Doval PAIS, A., «Homicidios», cit., p. 10; DAUnIS RodRíGUEZ, A., "La imprudencia», cit., pp. 8-9; HAVA GARcíA, E., "Responsabilidad», cit., pp. 15-19; MARTínez-Buján PÉREz, C., Derecho penal económico y de la empresa. Parte General (5. a edición). Tirant lo Blanch, Valencia, 2016, p. 403; Muñoz Conde, F. / García Arán, M., Derecho, cit., pp. 304, 306-307; y Quintero Olivares, G., Parte General, cit., pp. 440-441. Roxin, C., Derecho, cit., pp. 1013-1017, señala como ejemplo que quien conduce un coche cuyo defecto de motor advierte o debiera advertir actúa imprudentemente, pero no aquél que no posee indicios de ese daño. Tampoco sería imprudente una conducción brusca o acelerada por una experto en conducción en determinadas circunstancias. Además las capacidades especiales del autor pueden ser tenidas en cuenta para graduar la gravedad de la imprudencia. Por el contrario, especifica el autor que las capacidades inferiores a la media no pueden excluir el tipo imprudente, aunque podrían excluir el delito en sede de culpabilidad. También, Hava GARcía, E., La imprudencia, cit., pp. 185-186, aunque instando a no apreciar el criterio de forma mecánica. La autora señala que es cierto que el baremo de cuidado que resulte aplicable a este sujeto «especializado» es más exigente para él que para un individuo «normal», aunque una vez determinado ese baremo, aún habría que dilucidar si el autor supra-capacitado lo infringió de un modo grave o leve.

21 Vid., al respecto, por todos, Corcoy BidAsolo, M., «Homicidio y lesiones imprudentes cometidos con vehículos a motor o ciclomotor», en AA.VV. Derecho penal y seguridad vial. Estudios de Derecho Judicial, 114. CGPJ, Madrid, 2007, pp. 96-105, Luzón PEÑA, D-M., Lecciones, cit., pp. 296-299; o las importantes SSTS 464/2016, de 31 de mayo, 79/2013, de 8 de febrero, 186/2009, de 27 de febrero, 181/2009, de 23 de febrero, 282/2005, de 4 de marzo, 1111/2004, de 13 de octubre de 2004, 966/03, de 4 de julio, 665/2004, de 30 de junio, 1763/2001, de 19 de diciembre, 2235/2001, de 30 de noviembre, 291/2001, de 27 de febrero; y 1166/1998, de 10 de octubre, a los efectos de aplicar el delito del art. 142 o la falta del art. 621. La STS de 27 de febrero de 1985 se refería a la imprudencia grave como la «eliminación de la atención más absoluta, la ausencia de los cuidados más elementales que la vida de relación exige, conculcándose deberes fundamentales que exige la convivencia»; mientras que la leve la "omisión de la atención normal o debida» o la "omisión de la diligencia media acostumbrada en la esfera en la que se desarrolle la actividad de que se trate». Por su parte, la STS 1823/2002, de 7 de noviembre resume la doctrina de la sala con la que identifica la imprudencia grave con la antigua (previa al Código de 1995) temeraria, y la leve con la antigua simple. 
algunos casos, si contribuye de un modo causal de cierta importancia en el resultado producido, implicar una degradación de la imprudencia, pues resulta menos evitable el riesgo en tales circunstancias ${ }^{22}$.

Resulta necesario partir de esta vieja conceptualización de la imprudencia y saber si la imprudencia menos grave es una nueva categoría de imprudencia, que por fuerza habría de estar entre las antiguas categorías de imprudencia grave y leve, o si abarca las mismas infracciones de cuidado que las de la anterior imprudencia leve.

\section{1. ¿Qué dice el Preámbulo de la LO 1/2015?}

En un primer momento, el Proyecto de reforma del CP de 2013 excluyó del ámbito penal la imprudencia leve, relegándola al ámbito civil, y mantuvo como delito los casos de muerte y lesiones causadas exclusivamente por imprudencia grave, introduciendo como novedad, en uno y otro caso, dos criterios para la valoración de la imprudencia: a) la gravedad del riesgo permitido creado y, en particular, si el mismo constituye una infracción grave o muy grave conforma a los dispuesto en la Ley de Tráfico $^{23}$ y b) la relevancia del riesgo creado en el contexto concreto en el que se lleva a cabo la conducta peligrosa. Esta propuesta de regulación fue duramente criticada por algunas asociaciones de víctimas de accidentes de tráfico, y por no poca doctrina penal, que vieron que la normativa proyectada se iba a traducir en una inevitable impunidad de resultados de extraordinaria gravedad cometidos por imprudencia que no pudiera calificarse de grave - y el archivo de causas por accidentes de tráfico-. También, porque se produciría un cambio de escenario de indudables repercusiones para el resarcimiento de los daños, al quedar cerrada la vía

22 Vid. Cerezo Mir, J., Curso, cit., pp. 184-185; Corcoy Bidasolo, M., El delito, cit., pp. 176-177; Díez Ripollés, J.L., Derecho penal español. Parte General (4. ${ }^{a}$ edición). Tirant lo Blanch. Valencia, 2016, p. 220, quien indica que la concurrencia de culpas puede rebajar la imprudencia pero nunca excluirla, pues no hay que obviar la inobservancia del cuidado debido por el autor; LuZón PeÑa, D-M., Lecciones, cit., pp. 303-304, que sí cree que puede excluirla si la imprudencia de la víctima es la única que determina objetivamente el curso del hecho, esto es, por falta de imputación objetiva del resultado a la conducta imprudente del autor, por ser inadecuado el curso causal, o por no realizar el resultado el peligro que quería evitar la norma de cuidado; y PÉREZ DEL VALLE, C., La imprudencia, cit., pp. 186-187. Así, también, la reciente SAP de Madrid 488/2016, de 21 de septiembre (caso "Madrid Arena»), o las ya clásicas SSTS de 12 de julio 1989, de 6 de febrero de 1987, y de 8 de junio de 1985. De parecer contrario, esto es, partidario de que la concurrencia de culpas no rebaja la imprudencia, Zárate Conde, A. / González Campo, E., Derecho penal. Parte General. La Ley. Madrid, 2015, p. 220.

${ }^{23} \mathrm{Vid}$. la crítica que efectúa Daunis RodríGueZ, A., «La imprudencia», cit., pp. 12-22, a este criterio, si hubiese sido finalmente incorporado en el Código, por suponer la vuelta de la derogada técnica de dotar a la infracción de reglamentos administrativos la categoría objetiva de elemento nuclear y delimitador del delito imprudente. 
más expedita del proceso penal para la obtención de indemnizaciones, obligando a la víctima a acudir a la vía civil, con mayores costes y dificultades ante el hecho de que tenga que costear los peritajes para determinar la dinámica del accidente ${ }^{24}$. Ante este escenario de insatisfacción ${ }^{25}$, se terminó por incluir la imprudencia menos grave en la LO 1/2015, de 30 de marzo, de reforma del Código penal, concepto que, sin embargo, no se define en su articulado. Las enmiendas 819 y 820 del Grupo Popular dieron la vigente redacción de los apartados 2 de los arts. 142 y $152 \mathrm{CP}^{26}$.

Sobre esta inclusión, el legislador de 2015, en el apartado XXXI del Preámbulo de la LO 1/2015, indica que «en cuanto al homicidio y lesiones imprudentes, se estima oportuno reconducir las actuales faltas de homicidio $y$ lesiones por imprudencia leve hacia la vía jurisdiccional civil, de modo que solo serán constitutivos de delito el homicidio y las lesiones graves por imprudencia grave (apartado 1 del artículo 142 y apartado 1 del artículo 152), así como el delito de homicidio y lesiones graves por imprudencia menos grave, que entrarán a formar parte del catálogo de delitos leves (apartado 2 del artículo 142 y apartado 2 del artículo 152 del Código Penal). Se recoge así una modulación de la imprudencia delictiva entre grave y menos grave, lo que dará lugar a una mejor graduación de la responsabilidad penal en función de la conducta merecedora de reproche, pero al mismo tiempo permitirá reconocer supuestos de imprudencia leve que deben quedar fuera del Código Penal. No toda actuación culposa de la que se deriva un resultado dañoso debe dar lugar a responsabilidad penal, sino que el principio de intervención mínima y la consideración del sistema punitivo como última ratio, determinan que en la esfera penal deban incardinarse exclusivamente los supuestos graves de imprudencia, reconduciendo otro tipo de conductas culposas a la vía civil, en su modalidad de responsabilidad extracontractual o aquiliana de los artículos 1902 y siguientes del Código Civil, a la que habrá de acudir quien pretenda exigir responsabilidad por culpa de tal entidad» ${ }^{27}$.

24 Vid. Castro Corredoira, M. / Guinarte Cabada, G., "La reforma de los delitos de lesiones (arts. 157, 152 y 156)», en GonzÁlez Cussac, J.L. (Dir.), Comentarios a la reforma del Código penal de 2015 (2. ${ }^{\text {a }}$ edición). Tirant lo Blanch, Valencia, 2015, p. 499; LANZAROTE Martínez, P.A., "El nuevo», cit., p. 1737; y Morales Prats, F., "Artículo 142» en Quintero Olivares, G. (Dir.), Comentarios a la parte especial del Derecho Penal (10 . a edición). Aranzadi, Navarra, 2016, p. 68.

25 Vid., en este sentido, como ejemplos, la noticia del Periódico El mundo de 19 de enero de 2013: http://www.elmundo.es/elmundo/2013/01/10/espana/1357832213.html —fecha de consulta: 16-01-2017—; y del portal Ciclosfera: http://www.ciclosfera.com/ciclistas-yvictimas-de-accidentes-denuncian-codigo-penal/ —fecha de consulta: 16-01-2017-.

26 Vid., sobre la génesis parlamentaria de esta reforma, DE VICENTE MARTíNEZ, R., «La reforma», cit., pp. 51-55; y Doval PAIS, A., «Homicidios», cit., pp. 4-5.

27 Cabe indicar que la decisión de destipificar la imprudencia leve, que mayormente se venía aplicando en el ámbito del tráfico rodado, resulta opuesta a la de seguir con el expansionismo del Derecho Penal en este concreto ámbito. Especialmente tras la LO 15/2007, de reforma del Código penal, con la que se introdujeron nuevos delitos contra la seguridad vial de peligro abstracto cuya afectación real a la vida e integridad corporal en forma de peligro ni siquiera viene exigida. Y ello no parece conciliar con aquella despenalización de conduc- 
De estas palabras se deduce, pues, que para el legislador de 2015 la imprudencia menos grave constituye una nueva categoría de imprudencia que alberga un nuevo concepto de imprudencia, que ha de ser precisado, pues se sitúa entre la imprudencia grave, que recibe más pena, y la imprudencia leve, que se descriminaliza y reconduce a esas otras ramas del ordenamiento menos intrusivas ${ }^{28}$. Pero no establece ninguna pauta con la que precisar dicho concepto, es decir, con la que determinar en qué punto entre las imprudencias grave y leve queda la menos grave ¿Recogería los supuestos menos graves de la imprudencia grave? ¿Los más graves de la leve? ¿Ambos? Fíjese que las dos últimas soluciones no implicarían una total desaparición de la vieja imprudencia leve del Código Penal, pues al menos los casos más graves abarcados por ella seguirían siendo penalmente relevantes. Por otra parte, las soluciones primera y tercera implicarían una modificación del contenido y alcance de la imprudencia grave que tendrían que ser delimitados, por lo que la reforma sí supondría, de estimarlo así, una modificación de esta clásica categoría de imprudencia.

A nuestro juicio, el legislador de 2015 efectúa en el párrafo del Preámbulo transcrito una contradicción de la que se deduce la solución que quizá ha tenido en mente con la reforma. En un primer momento señala que «se estima oportuno reconducir las actuales faltas de homicidio y lesiones por imprudencia leve hacia la vía jurisdiccional civil». Parece entenderse que se trata de una reconducción de «todos» los casos de imprudencia leve. Pero a continuación indica que la nueva categorización de la imprudencia que se introduce en el Código Penal "permitirá reconocer supuestos (algunos) de imprudencia leve que deben quedar fuera del Código Penal», por tanto, no todos, lo que implica que algunos, y se ha de entender los más graves, aún serán penalmente relevantes ${ }^{29}$. Este entendimiento claramente descarta una equiparación entre imprudencia leve y menos grave ${ }^{30}$, pero, además, parece encajar con la segunda de las soluciones propuesta. Del Preámbulo parece desprenderse, pues, la idea de que la imprudencia menos grave pasaría a abarcar los casos más graves de la antigua imprudencia leve. Pero lo cierto es que en ningún momento se afirma de un modo expreso. Tendrá que ser la jurisprudencia y la doctrina las que lo determinen, así como los matices diferenciadores entre las actuales categorías de imprudencia.

\footnotetext{
tas que, aunque sea por imprudencia leve, sí ocasionan ya la muerte o una efectiva lesión corporal. Así, FERNÁNDEZ HERNÁNDEZ, A., «Supresión», cit., pp. 55-56.

${ }_{28}$ Se refieren a una supresión de las antiguas faltas por imprudencia leve, DíEz RIPOLLÉS, J.L., «Sucintas», cit., p. 51; FARALDO CABANA, P., «La despenalización», cit., p. 5; y FERNÁNDEZ HERNÁNDEZ, A., «Supresión», cit., p. 69.

29 Vid., también, Daunis Rodríguez, A., «La imprudencia», cit., p. 29.

30 Cfr. Daunis Rodríguez, A., «La imprudencia», cit., p. 29.
} 


\subsection{Otros argumentos en la línea de lo que dice la LO 1/2015}

Además de lo establecido por el Preámbulo de la LO 1/2015, existen otros argumentos con los que llegar a esta consideración sobre lo que abarca la nueva imprudencia menos grave, o al menos, como mínimo, con los que requerir a esta imprudencia un mayor desvalor de acción, en lo que a la infracción de cuidado se refiere, respecto de la derogada imprudencia leve.

No ha de pasar desapercibida, en primer lugar, la nueva adjetivación utilizada por el legislador, esto es, que la imprudencia sea menos grave en vez de leve. El primer término ya parece referirse a algo de más intensidad o relevancia en el comportamiento infractor de la norma de cuidado $^{31}$.

Otro argumento de naturaleza material tiene que ver con las diferencias de pena entre las viejas y nuevas figuras. Los nuevos delitos de homicidio y lesiones por imprudencia menos grave reflejan una importante agravación penológica. Se castigan con multa de 3 a 18 meses y de 3 a 12 meses, respectivamente (con anterioridad, como faltas de homicidio y lesiones por imprudencia leve, con multa de 1 a 2 meses, y de 10 a 30 días, también respectivamente). E incluso se amplía el límite superior de la pena de privación del derecho de conducir en el delito de homicidio cometido por imprudencia menos grave, que pasa de 12 a 18 meses. Esta elevación de la pena, así como las más gravosas consecuencias que conlleva la comisión de delitos leves y no de faltas (en materia de prescripción delictiva, cancelación de antecedentes penales o punición de la tentativa ${ }^{32}$ ), evidencian que la distinción entre imprudencia menos grave y leve no puede ser solo terminológica, y que la imprudencia menos grave se constituye como una nueva categoría de imprudencia que debe exigir una infracción más reprochable de un deber de cuidado o que este deber sea de mayor relevancia ${ }^{33}$.

31 Vid. Lanzarote Martínez, P.A., «El nuevo», cit., p. 1740.

32 Dictamen 2/2016, p. 22.

33 Así, Díez Ripollés, J.L., Derecho penal, cit., pp. 217-218, que indica que ha habido una «importante» elevación de las penas en las nuevas categorías de imprudencia menos grave, y por ello concede a esta una operatividad más reducida que la que tenía la antigua imprudencia leve: los casos más graves de esta última. Sin embargo, el autor no da luego mucha relevancia al dato, pues estos casos «más graves» son la «mayoría» que con anterioridad se consideraban de imprudencia leve. También se refieren a este argumento, JAÉN Vallejo, M. / Perrino Pérez, A.L., La reforma penal de 2015 (Análisis de las principales reformas introducidas en el Código penal por las Leyes Orgánicas 1 y 2/2015, de 30 de marzo). Dykinson, Madrid, 2015, p. 206; LanZarote MarTínez, P.A., «El nuevo», cit., p. 1740; MaNZANAREs SAMINEgo, J.L., La reforma del Código penal de 2015. Conforme a las Leyes Orgánicas 1 y 2/2015, de 30 de marzo. La Ley. Madrid, 2015, p. 162; Morales Prats, F., «Artículo 142», cit., pp. 68-69; y el AAP de Mérida 199/2017, de 16 de julio. Otro argumento pudiera residir en la distinta abarcabilidad de la conducta típica de alguna nueva figura. Las lesiones cometidas por imprudencia leve podían consistir en cualquiera de las lesionas 
Por último, cabe indicar que con la reforma de 2015 la imprudencia grave parece que no ha tenido alteración como categoría. Ni la ha sufrido terminológicamente ni tampoco los delitos en los que se prevé han sufrido modificaciones de peso en cuanto a sus penas que pudieran reflejar un cambio en cuanto a su contenido. Por ello, parece oportuno, en principio, seguir ciñéndola a la definición y alcance que ha venido teniendo hasta ahora en sede jurisprudencial y doctrinal. Cierto es que en lo que a nuestro objeto de estudio se refiere se prevé una modificación en el delito de lesiones por imprudencia grave del art. 152.1.1. ${ }^{\circ} \mathrm{CP}$, que consisten en realizar las lesiones del art. $147.1 \mathrm{CP}$ con esta clase de imprudencia. Desde 2015 se recoge la aplicación alternativa de las penas de prisión de 3 a 6 meses o de multa de 6 a 18 meses, cuando antes de la reforma de 2015 esa misma conducta tan solo se castigaba con la pena de prisión de 3 a 6 meses. No obstante, esta modificación se debe al cambio del contenido de ese tipo básico de lesiones dolosas del art. 147.1 CP que tras la eliminación de las faltas dolosas de lesiones muta de contenido para, además de sancionar las lesiones que requieren objetivamente para su sanidad una primera asistencia facultativa y un tratamiento médico o quirúrgico, incorporar también las lesiones con estas consecuencias que fueren de menor gravedad, atendidos el medio empleado o el resultado producido, que antes eran constitutivas del tipo atenuado del art. 147.2 CP. Y los comportamientos de lesiones que eran constitutivos de falta que consisten en causar a otro una lesión no incluida en el apartado anterior (no tratamiento médico o quirúrgico) se recogen ahora en el actual 147.2 CP. De ahí que se haya modificado también la respuesta punitiva del art. 147.1 CP que antes solo consistía en la pena de prisión de 6 meses a 3 años y ahora en la aplicación alternativa de las penas de prisión de 3 meses a 3 años o multa de 6 a 12 meses, habiéndose añadido precisamente esta segunda alternativa para abarcar aquellas lesiones de menor gravedad del antiguo 147.2 CP que resultan ahora subsumibles en el delito del art. $147.1 \mathrm{CP}^{34}$. Sin embargo, esta modificación de la pena

recogidas por cualquiera de los tipos dolosos cometidas, claro es, por esa imprudencia, mientras que en la actualidad solo se castigan por imprudencia menos grave las lesiones de los arts. 149 y $150 \mathrm{CP}$, esto es, las más graves que ocasionan la pérdida o la inutilidad de un órgano o miembro principal o no, de un sentido, la impotencia, la esterilidad, una deformidad (grave o no), o una grave enfermedad somática o psíquica. El resto son ahora atípicas. Es cierto que lo que aquí se valora no es el desvalor de resultado producido sino el desvalor de acción que se requiere al proceder «imprudente». Pero es cierto que si el legislador penal ha optado por sancionar penalmente por imprudencia menos grave solo los casos más graves y contundentes contra bienes personales (homicidio y lesiones) y ahora se exige un mayor nivel de gravedad a ellos (solo las lesiones del 149 y 150), pudiera al menos no descartarse que correlativamente la infracción del deber de cuidado exigido para aplicar la imprudencia menos grave deba ser mayor que el de la leve. No obstante, no es este un argumento sólido.

${ }^{34}$ Vid. CASTro Corredoira, M. / Guinarte CABADA, G., «La reforma», cit., p. 497; y TAMarit Sumalla, J.M., .De las lesiones», en Quintero Olivares, G. (Dir.), Comentarios a la parte especial del Derecho Penal (10 . a edición). Aranzadi, Navarra, 2016, p. 94. 
del art. 152.1.1. ${ }^{\circ} \mathrm{CP}$ no tiene nada que ver con la naturaleza de la imprudencia grave en sí, sino con el contenido del delito de lesiones, el cual varía, se amplía. Por ello, el cambio no debe afectar a la conceptualización que se haya de tener de la imprudencia grave, sobre todo cuando, se insiste, esta se sigue castigando en el resto de figuras delictivas en las que se recoge de igual modo que antes de 2015.

Por tanto, de estos argumentos y de las palabras del Preámbulo de la LO 1/2015 parece deducirse que la solución más razonable es considerar que la imprudencia menos grave constituye un concepto nuevo y autónomo que pasaría a abarcar los supuestos más graves de la antigua imprudencia leve. ¿Quizá la omisión de algunas, pero no todas, de las medidas elementales de control o cuidado?, ¿la de una única medida elemental de control junto con otras no elementales? Resulta una labor de determinación difícil, claro está, pero de vital trascendencia, lo que demanda compromiso y precisión por parte de los Tribunales, que serán los que tendrán que hacerlo ante la ausencia de una definición de las clases de imprudencia en el Código. Sin ese compromiso y precisión se corre el riesgo de que termine ocurriendo que la imprudencia menos grave y leve se equiparen en la práctica, y ello implicará un enorme incremento de las penas previstas en los nuevos delitos para los mismos hechos ${ }^{35}$. Con este fin, entre otros, surgió el Dictamen 2/2016 del Fiscal de Sala Coordinador de Seguridad Vial que se analiza a continuación, aunque con carácter previo se hará mención al estado de la cuestión en la doctrina y la jurisprudencia.

35 Fernández Hernández, A., "Supresión», cit., p. 69. Este incremento se contradiría con el deseo del legislador, explicitado en el Preámbulo de la Ley 1/2015, de reservar la vía penal para los supuestos de hecho más graves, salvo que esta no sea realmente una de las finalidades buscadas. Fernández Hernández, A., "Supresión», cit., pp. 80-81, considera, de hecho, que ese incremento penológico de la delincuencia de menor gravedad o de baja intensidad que sancionaba las derogadas faltas constituye uno de los «ocultos» fines político-criminales buscados por el legislador con su despenalización. No se refiere a ese fin, pero sí demuestra que la conversión de faltas en delitos supone un verdadero aumento de la gravedad de las penas de muchos de estos actos de delincuencia menor que antes eran faltas, así como de las consecuencias derivadas de la nueva configuración como delitos (a efectos de punición de tentativa, aumento del plazo de prescripción y existencia de antecedentes penales), CUGAT MAURI, M., "Consecuencias», cit., pp. 227-236; y Faraldo Cabana, P., «La despenalización», cit., pp. 15-18. Esta segunda autora indica que la despenalización de muchas faltas y su reconducción a la potestad sancionadora de la Administración, especialmente las atentatorias del orden público, no responde al respeto del principio de intervención mínima, sino a una más eficaz actividad represora de la Administración sobre la ciudadanía en esta materia, pues en el orden administrativo existe una presunción de veracidad de los agentes y cuerpos de policía, se dificulta la interposición de recursos contra las sanciones con estrategias como la reducción de su importe si se paga por adelantado o la obligación de pagarla para poder recurrir, y se oculta más fácilmente dicha actividad de represión, pues este tipo de actividad se suele vincular de forma más reducida al ámbito de lo penal y penitenciario; vid., misma autora, y obra, pp. 2224. 


\section{Estado de la cuestión en la doctrina y la jurisprudencia}

Todas las posibilidades de definición de la imprudencia menos grave y de delimitación de su campo de acción apuntadas supra han sido seguidas, con mayor o menor fundamentación, por algún sector de la doctrina penal tras la entrada en vigor de la reforma de 2015. Se pueden dividir en cuatro posibilidades ${ }^{36}$ :

1) identificarla con la imprudencia leve, de modo que el cambio sería únicamente terminológico. Ello respondería a la intención de convertir las antiguas faltas en delitos leves, lo que se vería apoyado por el hecho de que las imprudencias menos graves se aprecien solo con respecto a los mismos delitos que antes la imprudencia leve, y seguirían enjuiciándose por el juicio de faltas, ahora denominado «procedimiento para el juicio sobre delitos leves» ${ }^{37}$;

2) identificarla con los supuestos más graves de la imprudencia leve, sin detraer ninguno de la imprudencia grave ${ }^{38}$-lo que esencialmente vendría fundamentado por los argumentos expuestos en el

36 A ellas ya se referían, Lanzarote Martínez, P.A., «El nuevo», cit., pp. 1739-1740; y RAMÓN RIBAS, E., "La responsabilidad personal por impago de multa», en QUINTERO OLIVARES, G. (Dir.), Comentario a la reforma penal de 2015. Thomson Aranzadi, Navarra, 2015, pp. 118-119.

37 Así, Frías Martínez, E., «Artículo 142», en Roma Valdés, A. (Dir.), Código penal comentado. Bosch. Barcelona, 2015, p. 273; y LANZAROTE MARTínEZ, P.A., «El nuevo», cit., p. 1739.

38 De esta opinión, Daunis Rodríguez, A., «La imprudencia», cit., pp. 36-38; DíEz RiPoLLÉs, J.L., Derecho penal, cit., pp. 217-218, aunque indicando que abarcaría la mayoría de los casos anteriormente constitutivos de imprudencia leve, sin perjuicio de que «algunos» queden destipificados; Luzón PEÑA, D-M., Lecciones, cit., p. 299, que parece llegar a la misma consideración al indicar en un primer momento que «al menos por arriba su límite o frontera y por tanto el contenido de la imprudencia menos grave coincide exactamente con el del anterior concepto de imprudencia leve» aunque, a continuación, especifica que "sí puede sostenerse debido al cambio de nombre - que al fin y al cabo evoca una entidad media-es que, por abajo, en las infracciones leves o poco relevantes del deber de cuidado, aunque produzcan como resultado una muerte o lesiones graves, se puede ser más generoso en la consideración de una imprudencia como mínima, equiparando los supuestos de imprudencia leve menor a la imprudencia levísima y llevándola por ello a la atipicidad penal»; MuÑoz RuIZ, J., «Delitos contra la vida y la integridad física», en MorILlas CUEva, L. (Dir.), Estudios sobre el Código penal reformado (Leyes Orgánicas 1/2015 y 2/2015). Dykinson, Madrid, 2015, pp. 348 y 365; Romeo CASABONA, C.M., "El homicidio», cit., p. 18, cuando señala que la imprudencia menos grave debe dejar un espacio para los supuestos teóricamente despenalizados, lo que deberá construir la jurisprudencia con presupuestos diferentes a los pasados, con el fin de que se evite un castigo encubierto de la antigua imprudencia leve; SuÁREZ-MiRA RoDRíGUEZ, C., «Del homicidio y sus formas (arts. 138 y ss.)», en GonZÁlez Cussac, J.L. (Dir.), Comentarios a la reforma del Código penal de 2015 (2. ${ }^{\text {a }}$ edición). Tirant lo Blanch, Valencia, 2015, p. 488; y Zárate Conde, A. / González CAmpo, E., Derecho penal, cit., p. 224, cuando señalan que la imprudencia menos grave requerirá «un plus de intensidad respecto a la que anteriormente era considerada leve». 
epígrafe 3.2. de este trabajo- con las consiguientes repercusiones en el derecho transitorio centradas en la posibilidad de aplicación retroactiva de la nueva categoría de imprudencia leve más beneficiosa para el reo en supuestos antes catalogados de imprudencia leve que deban ser reconducidos al orden civil.

3) identificarla con los casos menos graves de la imprudencia gra$v e^{39}$, con las consiguientes repercusiones en el derecho transitorio centradas en la posibilidad de aplicación retroactiva de la nueva categoría más beneficiosa para el reo en supuestos previamente catalogados de imprudencia grave y que pudieran encajar ahora en la menos grave, y en el hecho de que «todas» las imprudencias antes consideradas leves quedan descriminalizadas por la LO 1/2015;

4) identificarla con una imprudencia intermedia entre la grave y la leve que abarcaría los casos menos graves de la primera y los más graves de la segunda ${ }^{40}$, con similares repercusiones en el derecho transitorio al poder llegar a resultar la nueva categoría más beneficiosa para el reo.

Por lo que respecta a la jurisprudencia, no se aprecia una tendencia unificadora en la praxis judicial posterior al 1 de julio de 2015. Hay fallos que siguen cualquiera de las cuatro posibilidades de conceptualización que se acaban de exponer. De hecho - y el Dictamen 2/2016 deja constancia de ello- la mayor parte de los pronunciamientos no se esfuerzan por elaborar un concepto en profundidad de la imprudencia menos grave, ni en el ámbito del tráfico vial ni en cualquier otro, limi-

39 Así, Doval PaIs, A., «Homicidios», cit., pp. 7-8, quien la cataloga de «subespecie» o «especie menor» de la imprudencia grave; y también parece ser la postura de TAMARIT Sumalla, J.M., «De las lesiones», cit., p. 119, cuando señala que «la distinción entre imprudencia grave y menos grave es pues una diferenciación en el seno de las lesiones anteriormente definidas como graves, por lo que debe interpretarse que los supuestos en los que, según el criterio asentado jurisprudencialmente, habia que considerar como leve la imprudencia, han quedado fuera del sistema penal».

${ }^{40}$ Así, Lanzarote Martínez, P.A., «El nuevo», cit., p. 1740; y Molina Fernández, F., «Dolo, imprudencia y error», en AAVV. Memento práctico. Penal 2017. Francis Lefebvre, Madrid, 2016, pp. 292-293. También se refieren a que la imprudencia menos grave ocupa un lugar intermedio entre la grave y la leve, pero sin determinar qué casos de una u otra abarcaría, Carbonell Mateu, J.C., «Homicidio y sus formas (I): homicidio», en González Cussac, J.L. (coord.), Derecho penal. Parte especial (5. a edición). Tirant lo Blanch, Valencia, 2016., p. 55; y Muñoz Cuesta, J. / RuIz de ERenchun Arteche, E., Cuestiones prácticas sobre la reforma penal de 2015, Aranzadi, Navarra, 2015, pp. 120-122, aunque los segundos autores parecen inclinarse por considerar que abarcan los casos más graves de la antigua imprudencia leve, pues afirman que tanto el homicidio como las lesiones por imprudencia grave han quedado tal y como se contenían en el texto antes de la reforma. Señalan que «sin ser tan grosera o inexcusable como la grave, ni tan liviana, rozando el caso fortuito como la leve, pero sí interpretada como la falta de diligencia exigible al hombre medio en el hecho que desarrolla». 
tándose simplemente a aplicar o no esta novedosa categoría de imprudencia al caso concreto ${ }^{41}$.

Así, por ejemplo, las SSAP de Madrid 789/2015, de 7 de diciembre, y $561 / 2015$, de 4 de septiembre, identifican sin argumentación alguna, al menos formalmente, la imprudencia menos grave con la leve. Por contra, la SAP de Madrid 865/2015, de 19 de octubre, y los AAP de Mérida 199/2016, de 16 de julio, y de Albacete 569/2015, de 16 de diciembre, también sin argumentación señalan que la imprudencia menos grave no puede entenderse como imprudencia leve. Dentro de esta segunda consideración, las SSAP de Cáceres 33/2016, de 22 de febrero, y 13/2016, de 20 de enero - mencionadas por el Dictamen-, identifican la imprudencia menos grave con los casos más graves de la antigua imprudencia leve. Por su parte, las SSJP de lo Penal de Pamplona 279/2015, de 24 de septiembre ${ }^{42}$, y de Valladolid 226/2014, de 2 de marzo de 2016, parecen referirse a una triple clasificación de la imprudencia en la que la menos grave se situaría en un término medio que abarcaría casos en los que superando el ámbito de protección de la imprudencia leve no guardan tanta gravedad como para ser introducidas en la grave. Con esa referencia a un "término medio", aunque sin decirlo con claridad, parecen optar por convertir la antigua división doble de la imprudencia entre grave y leve, abarcando cada una un 50\% de los casos de imprudencia, en triple, abarcando cada una un 33,3\% de los casos, que habrían de ser los menos graves de la antigua imprudencia grave y los más graves de la antigua imprudencia leve. Finalmente, en las SSAP de Las Palmas 366/2016, de 25 de octubre, de Almería 491/2015, de 29 de octubre ${ }^{43}$, y de Tenerife 421/2015, de 1 de octubre, la imprudencia menos grave se identifica con algunos casos que se extraen de la antigua imprudencia grave (se entiende los casos de menor gravedad), por lo que aplican retroactivamente la nueva categoría ${ }^{44}$. Pero incluso hay sentencias, como las SSAP de Almería 88/2017, de 6 de marzo, de Soria 59/2015, de 15 de julio, y de Madrid $387 / 2015$, de 10 de julio, que aplican retroactivamente la nueva categoría de imprudencia por ser más favorable al reo pero sin especificar qué so-

41 Vid. Dictamen 2/2016, pp. 17-20.

42 Esta sentencia enjuiciaba un caso ajeno al tráfico viario en el que un primer momento señala que «la actual imprudencia menos grave se sitúa (...) en un término medio, en el que si bien no hay una patente infracción de las elementales normas de prudencia, sí que se infringen deberes de cuidado relevantes, por contraposición a la imprudencia simple, que «representa la infracción de un deber de cuidado de pequeño alcance»... por lo que «los hechos tendría encaje en la fecha que sucedieron en la imprudencia leve y, tras la reforma, en la menos grave», rechazando la aplicación retroactiva de la nueva categoría de imprudencia por ser más perjudicial para el reo.

43 Esta sentencia se refiere a "grados de gravedad» de la imprudencia delictiva y que la conducta enjuiciada era de menor gravedad dentro de la gravedad, por tanto, constitutiva de imprudencia menos grave, aunque finalmente no aplica el delito por ser el resultado lesivo del art. $147 \mathrm{CP}$.

${ }_{44}$ Dictamen 2/2016, pp. 19-20. 
lución de las dos últimas apuntadas siguen; esto es, la de que abarca un híbrido con los casos menos graves de la antigua grave y los más graves de la antigua leve o solo los menos graves de la antigua grave ${ }^{45}$.

Aunque no se circunscriba al ámbito vial, resulta necesario hacer una breve referencia a la valoración que sobre la cuestión se efectuó en el conocido caso «Madrid Arena», que evalúo la gravedad de la imprudencia de varios imputados: organizadores de un evento musical, así como personal de seguridad y del servicio médico del evento. La Audiencia Provincial de Madrid, en la SAP 488/2016, de 21 de septiembre, se decanta claramente por la opción 3, esto es, la identifica con los casos menos graves de la antigua imprudencia grave. Con respecto a los acusados que ejercían funciones coordinadoras del equipo de refuerzo de los vigilantes de la empresa contratada para la operativa de seguridad dice que «cabe entender que la imprudencia menos grave no se refiere al límite superior de aquéllas conductas que antes eran consideradas como leves y que el legislador ha querido expresamente despenalizar, sino que debe considerarse que, dentro de la imprudencia menos grave se encuentran supuestos que antes se englobaban en la imprudencia grave pero que, por la menor importancia y relevancia del deber de cuidado infringido, de conformidad con los requisitos objetivos y subjetivos exigidos por la Jurisprudencia para ello, y a los que con anterioridad se ha hecho referencia, pueden ser considerados como menos graves». Tras ser recurrida, el Tribunal Supremo, en la STS 85/2017, de 11 de diciembre, se pronuncia sobre la cuestión e indica que la vulneración del deber de cuidado es idéntica en las imprudencias grave y menos grave y la diferencia está en la intensidad o relevancia de la vulneración. La menor gravedad significa partir de una previa valoración de la entidad o intensidad en la infracción de los deberes referidos, constitutivos de la imprudencia grave que, ante las circunstancias concurrentes, se degrada o desvalora. Parece que sigue la misma postura de la Audiencia Provincial. También porque a continuación señala que «la nueva imprudencia menos grave tampoco se integra totalmente en la imprudencia grave, y no se nutre de las conductas más leves de la imprudencia». El uso del término «totalmente» - lo que resulta obvio- parece dar a entender que sí hay una integración parcial de la imprudencia menos grave en la grave. Y que "no se nutra de las conductas más leves de la imprudencia», podría entenderse como que no abarca ningún caso de la imprudencia leve - aunque fíjese que el texto citado finaliza refiriéndose a una «imprudencia» en general, no a la leve- . Sin embargo, la sentencia concluye a posteriori con una última referencia contradictoria, y contraria a los términos expresamente utilizados por la Sentencia de la Audiencia Provincial, al indicar que «la imprudencia menos grave (sí) ha de situarse en el límite superior de aquéllas conductas que antes eran consideradas como leves y que el legislador ha querido expresamente despenalizar». El límite

45 También, el AAP de Sevilla 286/2017, de 15 de marzo. 
superior de algo pertenece todavía a ese algo. En lo que aquí se refiere, el límite superior de la antigua imprudencia leve son los casos más graves que pertenecen a ella, por lo que con estos términos, el Tribunal Supremo, a mi juicio, muestra que se decanta por un cambio de interpretación y se adhiere a la postura 2 antes expuesta, la defendida en este trabajo, aunque, como se ha visto, no se haya mostrado con claridad al respecto.

Ante este panorama de incertidumbre y nula unificación de criterios en la doctrina y jurisprudencia, que se potencia por el hecho de que las sentencias de las Audiencias Provinciales apenas hayan accedido a revisión casacional, surge este Dictamen 2/2016 del Fiscal de Sala Coordinador de Seguridad Vial, al menos con la intención de arrojar algo de luz interpretativa sobre la cuestión.

\section{Análisis del Dictamen 2/2016 del Fiscal de Sala Coordinador de Seguridad Vial: conceptualización de la imprudencia en el ámbito del tráfico rodado}

El Dictamen 2/2016 surge con un declarado doble objetivo tras la que denomina «parcial despenalización» de comportamientos típicos que supone en dicha materia la supresión de las faltas de los arts. 621.1, 2 y 3 CP. Después de analizar los antecedentes históricos y parlamentarios y el contenido exacto de la reforma de 2015 en lo que la objeto de este trabajo se refiere, trata de establecer, en primer lugar, una definición de la imprudencia menos grave, y delimitar su campo de acción respecto de las otras dos categorías de imprudencia existentes: la grave, también sancionada penalmente como delito menos grave, y la leve, merecedora tras la reforma de archivo al reconducirse a la responsabilidad extracontractual o aquilina del art. $1902 \mathrm{CC}^{46}$. A continuación, ofrece una serie de criterios con los que guiar la actuación especializada del Ministerio Fiscal en el ámbito del riesgo constituido por el tráfico viario. Se trata de una suerte de pautas valorativas de la gravedad del hecho imprudente en este ámbito de riesgo, con el fin de separar la aplicación práctica de las tres categorías de imprudencia.

\subsection{Concepto de imprudencia «menos grave»}

En lo que se refiere al primero de sus objetivos, sin embargo, el Dictamen 2/2016 decepciona por su falta de claridad, al menos, en la determinación de qué casos de imprudencia vendría a abarcar la imprudencia menos grave con respecto a la situación anterior a la reforma.

46 Dictamen 2/2016, pp. 8-9. 
Sí es cierto que en las conclusiones recoge expresamente una serie de consideraciones que parecen claras. La primera que la imprudencia grave no sufre modificación alguna, y que sigue gozando del mismo ámbito de aplicación que hasta ahora. Por tanto, rechaza la interpretación de que la imprudencia menos grave detraiga casos o supuestos de la antigua imprudencia grave $e^{47}$, que implicaría modificar el ámbito de esta última. Por ello, no se pueden revisar sentencias de condena o calificaciones por delitos de imprudencia grave que pudieran entrar en la menos grave sobre la base de que la reforma sea más favorable para el reo ${ }^{48}$.

Como segunda consideración señala que, junto a las dos imprudencias penalmente reconocidas, la leve constituye ahora un tercer escalón reservado para los ilícitos civiles encuadrados en la culpa extracontractual (art. 1902 CC) ${ }^{49}$. Pero, y como tercera estimación, que la nueva imprudencia menos grave «es distinta de la anterior imprudencia leve... y de mayor cercanía a la grave, exigiendo la vulneración de deberes relevantes de cuidado, tratándose de un concepto autónomo» ${ }^{50}$.

Si la imprudencia menos grave es «distinta» y de mayor cercanía a la grave que la antigua leve, pero sin detraer ningún caso de la antigua grave, parece que solo se puede concluir que la imprudencia menos grave vendría a recoger los casos más graves que antes abarcaba la leve. No obstante, se trata de una deducción. El Dictamen no deja constancia expresa de esta delimitación.

Como se ha dicho, estas consideraciones se recogen en las conclusiones del Dictamen, pero parecen no conciliar con algunas afirmaciones que efectúa con carácter previo. Y es que llega a indicar que también es incorrecto señalar que la imprudencia menos grave detraiga supuestos de la leve anterior, pues se trata de una categoría o concepto con vida propia y distinto de la antigua leve, sustituida, y de la grave que se mantiene idéntica ${ }^{51}$. Y alude a razones procedimentales. Según palabras textuales del Dictamen, la reforma solo ha pretendido «mantener idéntica tutela penal para la imprudencia grave y depurar el segundo escalón en la gradua-

47 Dictamen 2/ 2016, pp. 64, 21 y 25. También rechaza (p. 21) la idea de una más exigente figura de la imprudencia grave, bajo el «empuje» de la menos grave, pues los nuevos arts. 142.1 y $152.1 \mathrm{CP}$ reiteran literalmente el texto legal anterior, tanto en el tipo como en la pena, con la salvedad de la alternatividad punitiva del art. 152.1.1. ${ }^{\circ} \mathrm{CP}$, lo que iría contra el principio de legalidad y de proporción, en el sentido de que no puede pretenderse un comportamiento de mayor reproche con la misma sanción punitiva, además de ser una solución discriminatoria y no justificada en relación con los restantes delitos imprudentes.

48 Dictamen 2/ 2016, pp. 64-65-25.

49 Dictamen 2/ 2016, p. 65.

50 Dictamen 2/2016, pp. 64 y 21-22.

51 Dictamen 2/ 2016, p. 26. Vid. Molina Fernández, F., «Dolo, imprudencia», cit., pp. 292-293, que también hace referencia al carácter confuso de la solución propuesta por el Dictamen. 
ción, la imprudencia leve en virtud del principio de intervención mínima. Desde la perspectiva procesal, se vislumbra con mayor claridad a la luz de la motivación del Preámbulo sobre la racionalización en el uso de los recursos de la justicia, sin duda referida al juicio de faltas, ahora procedimiento por delito leve, en el que se ventilaban cuestiones que tanto por la entidad de la imprudencia como del resarcimiento civil merecían a juicio del legislación su reconducción al art. $1902 C^{52}$ ». Por ello, «tanto antes como después del 1-7-2015 las acciones subsumibles en estos tipos son las mismas sin que se experimente reducción alguna del ámbito de aplicación de la norma. Lo que sucede, como se dijo, es que las praxis judiciales han conducido a que hechos merecedores del cauce procesal de diligencias previas y de una respuesta penal de conformidad con estos preceptos sean indebidamente derivados al juicio de faltas, hoy procedimiento por delito leve, e indebidamente calificados en el que hemos llamado segundo escalón en la graduación del injusto ${ }^{53}$ ». De estos, a mi juicio, confusos párrafos con respecto a lo establecido en las conclusiones parece deducirse que el Dictamen estima que la regulación de la imprudencia no ha cambiado, y que la nueva adjetivación solo trata de corregir una desafortunada práctica judicial a través de la cual se ubicaban incorrectamente en el viejo escalón de la imprudencia leve supuestos que, ya antes de la reforma, merecían ser objeto de enjuiciamiento civil ${ }^{54}$. No es que antes los casos de imprudencia se resolvieran penalmente como grave o leve en un 50\%. Ya existía la vía civil. Así, el adjetivo «menos grave» vendría a recalcar una mayor gravedad que ya se debía de exigir al segundo escalón penal antes de 2015.

De este modo, el Dictamen parece conciliar con lo que dice la justificación de las enmiendas 819 y 820 del Grupo Parlamentario Popular en el Congreso, que fueron las que finalmente introdujeron la imprudencia menos grave y dieron la vigente redacción a los apartados segundo de los arts. 142 y 152 CP. La primera de ellas dice que «la solución al problema puede encontrarse combinando los siguientes elementos: sustituyendo la anterior dicotomía imprudencia gravelleve por la de imprudencia grave/menos grave. De este modo, el lenguaje -especialmente en contraste con la regulación vigente- evidencia que existe un espacio de conductas leves (los meros despistes) que, si bien son responsabilidad de un conductor, no deben permitir calificar al responsable del hecho como un "delincuente». Estos supuestos de imprudencia "menos grave», que se limitarían a los casos de causación de lesiones de cierta gravedad, serían en todo caso constitutivos de delito (y no de una falta)... De este

52 Dictamen 2/ 2016, p. 25.

53 Dictamen 2/ 2016, p. 26.

$54 \mathrm{O}$ incluso - parece también vislumbrarse de las palabras citadas- trata de corregir la incorrecta ubicación de casos imprudencia grave que caían en el saco de la leve por la excesiva gravedad de las penas con las que se castiga aquella. 
modo, se garantiza que son sancionados penalmente todos (pero sólo) las conductas que superan una minima gravedad».

Alguna doctrina también se ha referido a este proceder judicial con el que se canalizaban como faltas conductas que carecían de una mínima relevancia penal, pero como el Juez tomaba conciencia de esa situación en un momento en el que ya tenía oportunidad de resolver sobre el importe de la indemnización que debe pagarse a la víctima, optaba habitualmente por calificar como falta cualquier ligera imprudencia que únicamente diese lugar a una levísisma pena de multa, y resolver sobre el verdadero fondo de la cuestión: la responsabilidad civil ${ }^{55}$. Ello se pretendería corregir con la instauración de esta triple graduación de la imprudencia. Y también terminar, así, con la indebida utilización del proceso penal con fines exclusivamente resarcitorios ya que en muchos casos el procedimiento se archivaba o el juicio concluía con una sentencia absolutoria una vez indemnizada la víctima, pues esta vía se utilizaba como el escenario más propicio en el que llevar a cabo las negociaciones entre aseguradoras y perjudicados ${ }^{56}$. El propósito de la utilización de la vía penal era simplemente el de obtener un informe médico forense de cara a cuantificar las lesiones que después serían indemnizadas por la compañía de seguros y que, tras una larga y costosa tramitación, las compañías y perjudicados se arreglaban en el mismo momento del juicio o, de lo contrario, y de ser la sentencia desestimatoria por ser los hechos de escasa entidad, se comenzaba un nuevo y largo periplo judicial en vía civil ${ }^{57}$. Esta situación se corregiría derivando los casos de escasa importancia a la vía civil.

Por otro lado, la doctrina también consideraba que el anterior modelo, en el ámbito de la seguridad vial, producía, por arriba, una degradación de las imprudencias, que casi habitualmente se calificaban con falta. Principalmente, por las elevadas penas con las que se castigaba la imprudencia grave, lo que derivaba en una tendencia a dejar para ella solo casos que fueren extremadamente graves, de especial o flagrante temeridad o de importante influencia del consumo de bebidas alcohólicas $^{58}$. Y ello motivado, también, por la benevolencia que los tribunales tendían a mostrar en el citado ámbito criminológico. Sin fundamenta-

55 Cfr. Castro Corredoira, M. / Guinarte Cabada, G., «La reforma», cit., pp. 498-499; Lanzarote Martínez, P.A., «El nuevo», cit., p. 1738.

56 LanZarote Martínez, P.A., «El nuevo», cit., p. 1740.

57 A esta justificación se refiere la citada enmienda 819 introducida por el Grupo Popular en el Congreso de Diputados, en torno a la reforma del Código penal aprobada por la LO 1/2015. Vid., también, JaÉn Vallejo, M. / Perrino Pérez, A.L., La reforma, cit., p. 210.

58 Cfr. Lanzarote Martínez, P.A., «El nuevo», cit., p. 1738-1739, quien indica que esta práctica quiso evitarse con la Instrucción 3/2006 FGE, que demandaba un pormenorizado estudio de los asuntos relacionados con las imprudencias punibles en el tráfico rodado. Según la Circular 10/2011 FGE se consiguió una moderación de dicha práctica. 
ción dogmática o político criminal sólida, solían considerar como imprudencias leves comportamientos que en esos otros contextos hubieren sido consideradas como graves $^{59}$. Quizá porque los juzgadores se suelen identificar en esta clase de delitos no solo con las víctimas, ya que la conducción de vehículos es una práctica común y cotidiana que ellos también desarrollan, lo que hace surgir en ellos, quizá, una resistencia a verse a sí mismos como delincuentes ${ }^{60}$. Los objetivos del cambio serían, pues, con la nueva terminología, acabar con esta extendida práctica judicial, tratando así de evitar que conductas imprudentes de cierta gravedad generadoras de graves consecuencias sigan siendo castigadas con penas muy leves ${ }^{61}$. En resumidas cuentas: evitar seguir con una interpretación restrictiva de la imprudencia grave y amplia de la leve que relegaba al ámbito del juicio de faltas supuestos de acciones imprudentes de cierta $\operatorname{gravedad}^{62}$.

No obstante, y aunque la nueva regulación sin duda pueda contribuir a reducir esta desafortunada práctica judicial ${ }^{63}$, que incluso haya justificado en parte el contenido de la reforma, hay datos y referencias en el Preámbulo de la LO 1/2015 que instan a considerar que va más allá, y que la regulación de la imprudencia ha variado en sentido material con respecto a la situación anterior. Como ya se ha dicho, el Preámbulo indica que «se estima oportuno reconducir las actuales faltas de homicidio y lesiones por imprudencia leve hacia la vía jurisdiccional civil», por tanto, considera que algo que antes era penal ahora lo será civil. Se recoge así una modulación de la imprudencia delictiva entre grave y menos grave, lo que dará lugar a una mejor graduación de la responsabilidad penal en función de la conducta merecedora de reproche, «pero al mismo tiempo permitirá reconocer supuestos (por tanto, no todos) de imprudencia leve que deben quedar fuera del Código Penal». Parece dar a entender que son solo algunos supuestos que antes eran catalogables en esta imprudencia los que ahora «deben quedar» fuera del segundo escalón. Estas palabras

59 Así, Corcoy Bidasolo, M., «Homicidio», cit., pp. 80-82; De Vicente Martínez, R., «La reforma penal en curso en materia de siniestralidad vial», en AA.VV. Derecho penal y seguridad vial. Estudios de Derecho judicial, 114. CGPJ, Madrid, 2007, p. 333; GonZÁLEZ CuSSAC, J.L., "La reforma penal de los delitos contra la seguridad vial», en AA.VV. Derecho penal y seguridad vial. Estudios de Derecho judicial, n. ${ }^{\circ} 114$. CGPJ, Madrid, 2007, pp. 281286; Magro Servet, V., "La derogación», cit., p. 1862; y Pla I Simón, S., "Protocolos de actuación y problemática de la actuación policial en materia de delitos contra la seguridad del tráfico», en Mir Puig, S. / Corcoy Bidasolo, M., Seguridad vial y Derecho penal. Análisis de la LO 15/2007, que modifica el Código penal en materia de Seguridad vial. Tirant lo Blanch, Valencia, 2008, pp. 345-346.

60 Vid. De Vicente Martínez, R., «La reforma», cit., pp. 285-286. También se generaba una cierta sensación de impunidad respecto de hechos delictivos graves cometidos por imprudencia grave, que eran objeto de archivo tras haber llegado a un acuerdo compensatorio la parte perjudicada con la compañía de seguros.

61 Lanzarote MartíneZ, P.A., "El nuevo», cit., p. 1740.

62 Lanzarote Martínez, P.A., «El nuevo», cit., p. 1739.

63 Daunis Rodríguez, A., «La imprudencia», cit., p. 39. 
evidencian un cambio en la regulación, y no una simple modificación de lenguaje. Además, el hecho de que la imprudencia grave no haya cambiado de referencia, ni tampoco de forma significativa la regulación de los delitos en los que se incluye —ni tampoco los operadores jurídicos venían demandando una menor respuesta penal a esta imprudencia ${ }^{64}$-, y que por el contrario sí hayan cambiado (aumentado) las penas de los delitos leves que ahora castigan la nueva imprudencia menos grave, evidencia un cambio que solo puede conciliar con considerar que la nueva categoría de imprudencia abarca los casos más graves de la antigua imprudencia leve; esto es, exige una gravedad mayor que merezca la considerablemente más elevada pena con la que se castiga ahora la nueva categoría de imprudencia ${ }^{65}$. Y ello con base en el principio de intervención mínima, que, en palabras del referido Preámbulo, determina que en la esfera penal deban incardinarse exclusivamente supuestos graves de imprudencia, "reconduciendo otro tipo de conductas culposas a la vía civil... a la que habrá de acudir quien pretenda exigir responsabilidad por culpa de tal entidad» ${ }^{66}$. El empleo del término "reconducir» conecta con esta postura, pues refleja que el legislador estima que supuestos que antes eran penales ahora dejan de serlo, al haber sido objeto de esa «reconducción».

Esta categorización de la imprudencia menos grave tiene trascendencia en materia de derecho transitorio. No con respecto a casos calificados de imprudencia grave antes de 2015, ya que esta categoría no ha variado. Pero sí cabría una aplicación retroactiva de la nueva regulación respecto de casos sentenciados antes de la reforma por los Juzgados de lo Penal como falta del art. $621 \mathrm{CP}$, esto es, como imprudencias leves, y que en apelación, tras la entrada en vigor de los cambios operados en 2015, se declara que la imprudencia no es suficiente para ser considerada menos grave. En estos casos, varias sentencias absuelven por haber sido la regulación nueva más favorable para el reo, pues tales casos quedarían relegados a la esfera civil ${ }^{67}$. En este sentido se expresa la Disposición Transitoria Cuarta de la LO 1/2015 que señala que: «1. La tramitación de los procesos por falta iniciados antes de la entrada en vigor de esta Ley, por hechos que resultan tipificados (ahora) como delitos leves, continuará sustanciándose conforme al procedimiento previsto para el juicio de faltas en el Libro VI de la vigente Ley de Enjuiciamiento Criminal. 2. La tramitación de los procesos por falta iniciados antes de la entrada en vigor de esta Ley

${ }^{64}$ Cfr. Daunis Rodríguez, A., «La imprudencia», cit., p. 36.

${ }^{65}$ Recordemos, que el derogado homicidio por imprudencia leve se castigaba con multa de 1 a 2 meses, ahora el cometido por imprudencia menos grave con multa de 3 a 18 meses; y las lesiones por imprudencia leve se sancionaban con multa de 10 a 30 días y ahora con multa de 3 meses a 1 año.

${ }^{66}$ Las palabras en cursiva son del Preámbulo de la LO 1/2015.

67 Vid., a modo de ejemplo, las SSAP de Palma de Mallorca 6/2017, de 25 de enero, de Madrid 212/2016, de 9 de mayo, de A Coruña 274/2015, de 31 de julio, y de Zamora 78/2015, de 7 de julio. 
por hechos que resultan (ahora) por ella despenalizados o sometidos al régimen de denuncia previa, y que lleven aparejada una posible responsabilidad civil, continuarán hasta su normal terminación, salvo que el legitimado para ello manifestare expresamente no querer ejercitar las acciones civiles que le asistan, en cuyo caso se procederá al archivo de lo actuado, con el visto del Ministerio Fiscal. Si continuare la tramitación, el juez limitará el contenido del fallo al pronunciamiento sobre responsabilidades civiles y costas, ordenando la ejecución conforme a lo dispuesto en la Ley de Enjuiciamiento Criminal». Fíjese que esta específica previsión de naturaleza transitoria viene a apoyar la posición aquí defendida. Es un importante argumento más. Solo se dedica a precisar cómo seguir con la tramitación de procesos iniciados por falta antes de 2015, esto es, procesos que lo eran por imprudencia leve, cuya apreciación haya podido cambiar o no con la reforma, por seguir siendo de imprudencia leve o haber mutado a menos grave. Pero no hay una disposición similar o paralela respecto a la tramitación de procesos iniciados por imprudencias graves que eventualmente hayan podido cambiar de consideración («menos grave») más favorable al reo. Se deduce, pues, que para el legislador, con la reforma, ha cambiado la operatividad de la imprudencia leve, así como que solo ha cambiado esta clase de imprudencia.

Sin embargo, cabe indicar que con respecto a esta cuestión transitoria, algún Tribunal ha optado incluso por no hacer distinción alguna, en el sentido de que debería aceptarse una más generosa anulación retroactiva de todas las condenas por imprudencia leve previas a 2015, incluyendo las relativas a casos que podrían ser constitutivos de imprudencia menos grave. Y para ello alega razones tales como la poca importancia de las penas asociadas a la imprudencia leve, la incertidumbre acerca de qué constituye ahora la imprudencia menos grave, las dificultades para revisar la entidad que tuvieron los hechos desde la nueva óptica - que quizá solo puedan deducirse de las penas impuestas-y el razonable deseo de ahorrar costes procesales ${ }^{68}$. También es cierto que, al margen de la graduación de la imprudencia como menos grave o leve a efectos retroactivos, las lesiones por imprudencia menos grave que ocasionan un resultado lesivo del art. 147.1 CP están ahora despenalizadas, cuando con anterioridad a 2015 eran sancionadas como falta por imprudencia leve. Por tanto, cabe la aplicación retroactiva de la nueva ley por ser más favorable al reo, aunque el comportamiento previo a 2015 de imprudencia leve pudiere entrar, tras esa fecha, dentro de lo que en el ámbito del desvalor de acción es imprudencia menos grave ${ }^{69}$.

En cuanto al concepto de imprudencia menos grave, el Dictamen señala que merece tal calificación la realización de actos que impliquen

68 Así, Doval Pais, A., «Homicidios», cit., p. 8; y Molina Fernández, F., «Dolo, imprudencia», cit., p. 293. Vid. las STS 644/2016, de 14 de julio.

69 Vid. Doval Pais, A., "Homicidios», cit., p. 7. 
cuantitativamente una vulneración de cierta significación o entidad de deberes de cuidado ${ }^{70}$, más allá que la simple infracción de estos, pero sin llegar a los niveles requeridos tradicionalmente a la grave. También cuando constatada ésta última imprudencia, las circunstancias concurrentes o infracciones de la víctima obliguen a su no consideración como grave $^{71}$. Además, los deberes de cuidado infringidos han de albergar una mínima trascendencia en lo que al desarrollo de una conducción segura se refiere.

La imprudencia leve atípica quedaría reservada, por exclusión de las otras dos categorías, para infracciones del deber de cuidado que no revisten singular significación o relieve (como los meros despistes, descuidos o distracciones momentáneas, que son más propios de una imprudencia inconsciente) o de deberes de cuidado de insuficiente entidad, en los que no exista un interés público relevante que tutelar ${ }^{72}$.

A modo de cierre, el Dictamen se aventura a efectuar definiciones en abstracto de las tres clases de imprudencia:

1) la imprudencia grave se identificaría con la vulneración de elementales normas de cautela o deberes de cuidado que son exigibles a cualquier persona, al menos cuidadoso de los sujetos;

2) la imprudencia menos grave con la omisión de la diligencia media o normal, de la infracción de normas de cuidado respetadas por el ciudadano medio;

3) la imprudencia leve vendría referida a la omisión de deberes de escasa relevancia que son respetados por los sujetos más diligentes, ciñéndose a poco más que a los meros descuidos ${ }^{73}$.

\subsection{Criterios de valoración de la gravedad de la imprudencia en abstracto}

El Dictamen declara que estos criterios son extraídos de la jurisprudencia de la Sala 2. ${ }^{a}$ TS de los últimos años sobre imprudencias de tráfico, siendo una actualización de los ya recogidos y constatados en textos anteriores como la Instrucción 3/2006, de 3 de julio, sobre criterios de actuación del Ministerio Fiscal para una efectiva persecución de los

70 También, Muñoz Conde, F. / García ArÁN, M., Derecho, cit., p. 308.

71 Dictamen 2/ 2016, p. 23.

72 Dictamen 2/ 2016, pp. 23-24. También, Ramos TAPIA, I., «Delito», cit., p. 129.

73 Dictamen 2/ 2016, p. 55. Así, también, DAunis RodRíguEZ, A., "La imprudencia», cit., p. 39; y LANZAROTE MARTíneZ, P.A., "El nuevo», cit., p. 1740, añadiendo que la imprudencia menos grave se definiría por exclusión por todas las conductas negligentes que no puedan estimarse como graves o leves. Vid., también, en estos términos la, previa a la reforma, SAP de Córdoba 73/2002, de 21 de junio. 
ilícitos penales relacionados con la circulación de vehículos a motor, y la Circular 10/2011, de 17 de noviembre, sobre criterios para la unidad de actuación especializada del Ministerio Fiscal en materia de seguridad vial, ambos de la Fiscalía General del Estado. Estos textos recogen principios y criterios generales de ponderación de la gravedad de ese hecho imprudente en cualquier ámbito. El Dictamen las adapta, claro está, a los nuevos términos introducidos por la reforma de 2015 y se centra en la valoración de la imprudencia en el ámbito específico del tráfico de automóviles, sin perjuicio de que resulten también de aplicación en todos los ámbitos de riesgo sobre los que se proyecten los arts. 142 y $152 \mathrm{CP}^{74}$.

En primer lugar, el Dictamen insta a la casuística, esto es, a efectuar un examen particularizado de cada caso concreto con sus diferentes circunstancias concurrentes. A continuación, establece unos criterios para efectuar una adecuada graduación de la gravedad del injusto imprudente en el tráfico vial, que impulsa para la unificación de criterios de los Juzgados y Tribunales. Son los siguientes:

1. Atender a los deberes de prevención y cuidado recogidos en la Ley de Seguridad Vial que forman parte del tipo objetivo del injusto imprudente ${ }^{75}$, y en concreto a su consideración en dicha Ley como deberes de carácter elemental o no. En línea de principio, la infracción de un deber de la primera categoría constituirá una imprudencia grave, mientras que la infracción de uno de la segunda implicará una imprudencia menos grave o leve. Se trata, pues, de atender al carácter elemental o no de la norma de orden socio-cultural o legal infringida. Para atender a la elementalidad de la norma, o del deber incluido en la norma, se ha de tener en cuenta si dicho deber está generalizado no sólo en su observación sino en la valoración que de él hace la sociedad otorgándole una significación de norma esencial para prevenir riesgos ${ }^{76}$.

2. Atender a la desaprobación jurídico-administrativa de la conducta, esto es, a cómo esta es sancionada en la Ley de Seguridad Vial:

74 Dictamen 2/ 2016, p. 33.

$75 \mathrm{Vid}$., sobre la determinación del cuidado exigible, como parte del tipo objetivo del tipo imprudente, Hava García, E., El tipo de injusto del delito imprudente. Un análisis de sus elementos orientado a la práctica. Rubinzal-Culzoni editores, Buenos Aires, 2012, pp. 95-105.

76 Vid. Dictamen 2/2016, pp. 33-35, en el que se cita la STS 2445/2001, de 22 de diciembre, cuando señala que dichos deberes o normas elementales vendrían recogidas en «un conjunto de reglas extraídas de la estimable cantera de lo común y diaria experiencia, muchas de ellas cristalizadas y consolidadas a través de normas reglamentarias o de otra indole, aceptadas e impuestas en la vida social y en cuyo escrupuloso entendimiento cifra la comunidad la conjuración del peligro acentuadas por sobrevenencia de circunstancias excepcionales; hallándose en la violación de tales principios o normas socioculturales o legales, la raíz del elemento de antijuridicidad detectable en las conductas culposas o imprudentes, al erigirse aquellos en reglas rectoras de un sector actuarial». 
como infracción muy grave, grave o leve. En línea de principio, la comisión de infracciones graves o muy graves implicará imprudencia grave, mientras que la comisión de infracciones leves de dicha normativa implicará imprudencia menos grave o leve. También, que la pluralidad de infracciones es indicativa de una imprudencia grave ${ }^{77}$.

Este criterio está en relación directa con el anterior, pues la valoración de la desaprobación de la conducta tiene en consideración la naturaleza e importancia del deber que se vulnera con dicha conducta, con independencia de que existan otros criterios que puedan servir para modular la valoración de la infracción. Así, en principio, los deberes asociados a ilícitos graves y muy graves de la Ley de Seguridad Vial son los relativos a: a) normas sobre adelantamiento; b) preferencia de paso; c) cambio de dirección o de sentido de la circulación; d) uso de la marcha atrás; e) sentido de la circulación y utilización de carriles y arcenes; f) conducción sin alumbrado; g) utilización de teléfonos móviles o auriculares; h) no uso de cinturón de seguridad, cascos o sistemas de retención infantil; i) no respeto de los semáforos; j) no respeto de las señales de stop o ceda el paso; k) no respeto de la distancia de seguridad entre vehículos y l) excesos de velocidad.

3. También ha de valorarse la mayor o menor gravedad, entidad o significación de los riesgos generados con la conducción, que implican la infracción de aquellos deberes de cuidado y que, dependiendo del caso, ponen en mayor o menor peligro, o lesionan, los bienes jurídicos de mayor relevancia (la vida y la integridad física) de los ocupantes de los vehículos y de los peatones. En principio, la generación de riesgos graves implicará la realización de una imprudencia grave, y la generación de riesgos que no sean graves implicará la realización de una imprudencia menos grave o leve.

Para valorar el nivel de gravedad de estos riesgos creados con la conducta, el Dictamen propone atender a: a) la conducta objetiva en sí misma; b) la elevada probabilidad o no de lesionar aquellos bienes jurídicos atendiendo a circunstancias como la densidad del tráfico y/o concurrencia de personas en el lugar; c) si la situación de riesgo es captada o conocida por el conductor o no; d) si el generador del riesgo (conductor) tiene o no, y en qué medida, conocimientos particulares sobre el contenido del concreto riesgo (si se trata de conductores profesionales, los meros

77 Dictamen 2/2006, pp. 35-36, en donde se dice que no solo se atenderá a la consideración muy grave, grave o leve de la conducta, sino también a la sanción imponible y a la pérdida de puntos del permiso de conducir. 
estados de desatención o distracción pueden merecer la consideración de imprudencias de gran entidad, en particular si se han vulnerado las condiciones de descanso ${ }^{78}$ ); y e) las condiciones psicofísicas relacionadas con la fatiga, el sueño o el cansancio que puedan constatarse en el caso. Sin embargo, el dictamen no se refiere como criterio al grado de evitabilidad de la conducta, esto es, a la posibilidad de neutralizar los riesgos generados con la actuación, criterio que sí ha tenido en cuenta alguna sentencia en otros ámbitos de actuación ${ }^{79}$.

4. Por último, el Dictamen recomienda examinar si los resultados de muerte o de lesiones son producto íntegro del riesgo no tolerable generado por el conductor y, en caso de que no sea así, en qué medida otros factores externos, como la autopuesta en peligro de la propia víctima, intermedian en la imputación objetiva del resultado a la acción de la conducción ${ }^{80}$. Se deberá examinar separadamente la conducta del conductor y de la víctima para determinar si el accidente es la realización total o parcial del riesgo generado por el primero o por la segunda para sí misma ${ }^{81}$. Además, aunque no lo diga el Dictamen, habría que limitar la esfera de resultados

${ }_{78}$ Vid. Dictamen 2/2006, pp. 65-66.

79 Sirva de ejemplo la SAP de Madrid 488/2016, de 21 de septiembre (caso «Madrid Arena»), cuando señala que "puesto que la posibilidad de neutralizar los riesgos de su actuación era menor que la de los otros acusados que resultan condenados, y por lo tanto la influencia que su conducta podría tener en la evitación del resultado, en un supuesto como éste de conductas concurrentes, también era inferior, en aplicación de la actual graduación de la imprudencia constitutiva de delito en el CP, se estima que su responsabilidad debe ser calificada, en beneficio de ambos acusados, como imprudencia menos grave».

${ }_{80}$ Dictamen 2/2006, p. 66. Vid., sobre la imputación objetiva en el delito imprudente, Corcoy Bidasolo, M., El delito, pp. 293-ss.; Díez Ripollés, J.L., Derecho penal, cit., pp. 213-215; Hava García, E., «Responsabilidad», cit., pp. 19-28; y en El tipo, cit., pp. 121-139; Muñoz Conde, F. / García Arán, M., Derecho, cit., pp. 309-312; QuinteRo Olivares, G., Parte General, cit., pp. 435-437. Vid., por ejemplo, el AAP de Madrid $1126 / 2016$, de 30 de noviembre, que no estima apreciar la imprudencia menos grave en un caso de homicidio por atropello de un peatón, aun habiendo sido comprobado el exceso de velocidad, porque el peatón cruzó por un lugar que no solo no estaba habilitado para ello sino que el tránsito de peatones por tal vía estaba terminantemente prohibido. Se trataba de una vía o arteria principal de circulación de la capital, con tres carriles principales en cada sentido de circulación en los que a su vez confluyen un carril bus y otro/os de incorporación a esta vía preferente, estando los pasos de peatones más próximos a 230 y a 145 metros. El conductor salía del túnel por el carril derecho, en sentido de circulación ascendente y con cambio de rasante. Era de noche, había iluminación artificial, y al final del cambio de rasante apareció el peatón por su izquierda. La visibilidad de lo que podía estar ocurriendo en los carriles de sentido contrario (que tenía que haber atravesado ya el peatón), era nula o mínima y era imprevisible que un peatón apareciera en la vía por la que circulaba. Además, el perito de parte considera obvio que el peatón atropellado pudo perfectamente evitar el accidente, de haber usado los pasos de peatones, así como que sus facultades estaban mermadas por una previa y abundante ingesta de alcohol.

81 Así, el Dictamen 2/2006, p. 66. 
imputables a la imprudencia del autor a aquellos que sean contrarios al fin de la norma violada, esto es, que guarden relación con ella ${ }^{82}$.

Como se dijo supra, estos criterios son de naturaleza abstracta. Han de ser objeto de una valoración conjunta e interconectada, sin perjuicio de que, según el caso, puedan ser de valoración alternativa y no acumulativa, pues una valoración estricta o mecánica puede llevar a situaciones irresolubles. Así, por ejemplo, la comisión de una infracción muy grave, constitutiva de imprudencia grave según el criterio 2, podrá ser también constitutiva de imprudencia menos grave o leve según el criterio 3, si parte de la generación de un riesgo que no es considerado grave. Es por ello que estos criterios deben ser tenidos como el punto de partida para efectuar la valoración de la gravedad del hecho imprudente, aunque pueda enfatizarse la presencia de solo uno o alguno de ellos si tienen especial relevancia o presencia en el supuesto de hecho concreto.

Algún autor, por ejemplo, considera oportuno no enfatizar la importancia del criterio 2 de atender únicamente a la infracción administrativa de la conducta en la Ley de Seguridad Vial, pues ello supondría una vuelta al derogado modelo de criminalización de la imprudencia basado en la infracción de reglamentos ${ }^{83}$. De hecho, algún pronunciamiento posterior, como los AAP de Madrid 156/2017, de 23 de febrero, y de Alicante 619/2016, de 15 de septiembre, lo llevan a la práctica. De un modo automático identifican plenamente la infracción de la normativa de seguridad vial con las dos modalidades de imprudencia punibles, al corresponder la imprudencia grave con las infracciones muy graves del art. 77 LSV, y la imprudencia menos grave con las infracciones graves del art. $76 \mathrm{LSV}^{84}$. Ello supone elevar la infracción administrativa a la categoría de penal solo por el hecho de que se haya dado el resultado prohibido en la norma

82 Cfr. Quintero Olivares, G., Parte General, cit., p. 443. Así, por ejemplo, la norma que limita la velocidad excesiva no tiene entre sus finalidades la de no atropellar a peatones que se ponen en curvas en medio de la carretera. En este caso, habrá un delito de conducción a velocidad excesiva, pero no un delito de homicidio o lesiones por imprudencia. También, Cerezo Mir, J., Curso, cit., pp. 183-184; y Corcoy Bidasolo, M., El delito, cit., pp. 561-ss.

83 Daunis Rodríguez, A., «La imprudencia», cit., pp. 12-22.

${ }^{84}$ Ambos pronunciamientos fueron emitidos por D. Vicente Magro Servet, que recoge su postura en: MAGRO SERVET, V., «Esquema sobre determinación de accidentes de tráfico a deriva al orden jurisdiccional penal tras la despenalización de las faltas de tráfico», en Diario La Ley, n. ${ }^{\circ}$ 8735, 2016, p. 8. De igual modo, Medrano Aranguren, A., Accidentes», cit., p. 175, recordando que para que la conducta sea delictiva habría que comprobar que con cada infracción de los arts. 77 y 76 LSV se produce el resultado lesivo que concretamente es requerido en los tipos de los apartados 1 o 2 del art. $152 \mathrm{CP}$, respectivamente. Vid. también el AAP de Murcia 864/2017, de 13 de octubre, que señala que la imprudencia grave abarcaría algunas conductas recogidas como infracciones muy graves en la normativa vial y la imprudencia menos grave algunas de las recogidas como infracciones muy graves o graves en la normativa vial. 
penal. Se trataría de una «responsabilidad objetiva», «estandarizada», de la imprudencia que castigaría por los resultados producidos y no por la naturaleza del actuar imprudente ${ }^{85}$, lo que implica obviar la verdadera esencia del delito imprudente - además del resto de criterios- que se encuentra en la mayor o menor intensidad de la infracción del deber de cuidado y, por tanto, de lesión o puesta en peligro de un bien jurídico penal. Y es que la infracción de un reglamento no tiene por qué implicar siempre la desatención de una norma penal de cuidado. Imagínese la conducción por encima de las tasas de alcohol permitidas o el saltarse una señal de ceda el paso que derivan en un atropello de un peatón o un ciclista que actúa también imprudentemente al ir influenciado por el alcohol o circular o cruzar por lugares inhabilitados. Estas circunstancias pueden mediatizar la infracción del deber de cuidado del autor, y no serían tenidas en cuenta de seguir únicamente el criterio $2^{86}$. Por ello es aconsejable atender a todos los criterios que puedan tener incidencia en la valoración de la imprudencia en el caso concreto ${ }^{87}$.

A modo conclusivo, con referencia a la imprudencia menos grave, el Dictamen señala que esta se da «cuando la vulneración del deber normativo de cuidado, aun siendo relevante, no alcance la suficiente gravedad o cuando constatada ésta las circunstancias concurrentes o infracciones de la víctima obliguen a la desvaloración o degradación. Por ello, la simple acreditación formal de las infracciones de las normas y deberes referidos (criterios 1 y 2)... no tiene por qué conducir automáticamente a la valoración como grave de la imprudencia, debiendo efectuarse un examen ad casum de la entidad del deber de cuidado infringido que podría dar lugar a la apreciación de la conducta imprudente como menos grave o, dependiendo del supuesto concreto, como leve» 88 .

85 Cfr. Daunis Rodríguez, A., «La imprudencia», cit., p. 13.

86 Vid. Daunis RodrígueZ, A., «La imprudencia», cit., pp. 17-20-

87 Cfr. Daunis Rodríguez, A., «La imprudencia», cit., p. 21.

${ }_{88}$ Dictamen 2/2016, pp. 54-55. Se hizo mención supra a la existencia de una Propuesta de Ley Orgánica de reforma del Código Penal, de 30 de junio de 2017, con la que se pretende añadir un párrafo a los delitos de homicidio y lesiones por imprudencia grave de los arts. 142 y $152 \mathrm{CP}$ con el siguiente tenor: "a los efectos de este apartado, se reputará en todo caso como imprudencia grave la conducción en la que concurra alguna de las circunstancias previstas en el artículo 379 del Código Penal», esto es, la conducción a velocidad excesiva, la influenciada por el consumo de alcohol o drogas o la que esté por encima de las tasas indicadas en el citado precepto. Se trata de una presunción iure et de iure de culpabilidad de dudoso respaldo constitucional que, de prosperar su inclusión en el Código, al ser de aplicación "en todo caso», dejaría sin utilidad los criterios expuestos por el Dictamen, ya que la gravedad solo se establecería a partir de una valoración de la conducta objetiva realizada. No se podrían tener en cuenta, otros factores como la probabilidad de lesión en función de la densidad del tráfico; si la situación de riesgo es captada por el conductor, los conocimientos particulares de este sobre el contenido del riesgo o si la victima intermedia de algún modo, con un actuar arriesgado, en la imputación objetiva del resultado a la acción de la conducción. Por poner un ejemplo: una conducción bajo la influencia de bebidas alcohólicas con las que se ocasionen unas lesiones a un peatón será considerada de lesiones por imprudencia grave aunque 


\subsection{Criterios de valoración de la gravedad de la imprudencia en concreto}

Estas pautas más concretas que se exponen a continuación no son sino indicadores u orientaciones que el Dictamen recoge en relación ya con particulares conductas al volante que constituyen infracciones de tráfico y que implican la vulneración de deberes de prevención y cuidado (criterios generales 1 y 2), con el fin de que puedan servir de ayuda unificada para la argumentación y el razonamiento de Jueces y Tribunales en su labor de valoración de la gravedad de la imprudencia, a los efectos de aplicar los tipos de los arts. 142 y $152 \mathrm{CP}$ o derivar el caso a la jurisdicción civil ${ }^{89}$. No obstante, la valoración que se realiza de cada concreta actividad tiene en cuenta, según las particularidades del caso, otros factores que puedan concurrir en, y mediatizar, la valoración del riesgo creado (criterios generales 3 y 4 ).

Esos concretos comportamientos «imprudentes» al volante, y los criterios a tener en cuenta para la valoración del grado o intensidad de la imprudencia son los siguientes:

1. Adelantamientos. Las normas de seguridad que los regulan (arts. 33-38 LSV) se consideran normas elementales, por lo que en principio su realización de un modo prohibido es indiciariamente constitutivo de imprudencia grave, salvo que atendiendo a las circunstancias concretas no se haya producido invasión del sentido contrario o cuando haya espacio suficiente entre el vehículo adelantado y los que le preceden, lo que puede derivar en una imprudencia menos grave. No se prevé la aplicación de la imprudencia leve.

2. Excesos de velocidad. Las infracciones de velocidad que detraigan 6 puntos del permiso según las tablas del Anexo IV LSV implicarán la apreciación de imprudencia grave; las que no implique la detracción de puntos implicarán la apreciación de imprudencia leve, mientras que las infracciones que detraigan 2 o 4 puntos estarían abonadas a la apreciación de imprudencia menos grave. No obstante, se subraya que esta estimación lo es con carácter general, pues en los dos últimos supuestos, si existen circunstancias concurrentes que signifiquen además otra vulneración de

aconteciese en una zona despoblada a altas horas de la noche, se circulase a velocidad adecuada y el peatón hubiese cruzado por una zona prohibida, e incluso si éste último lo hubiese hecho también bajo la influencia del alcohol. Se trata de una presunción de culpabilidad inadmisible que echaría por tierra cualquier esfuerzo evaluador de factores concurrentes que resulta necesario para determinar la mayor o menor gravedad de un determinado comportamiento imprudente.

89 Dictamen 2/2016, pp. 37-59. 
especiales deberes de cuidado (excesos de velocidad en curvas sin visibilidad) se podrá apreciar la imprudencia grave.

3. Maniobras de marcha atrás. Se insta a efectuar una valoración ad casum, pues pueden acontecer muy variadas circunstancias a tener en cuenta, como el tipo de vía, la velocidad con que se haga, la asunción o no de alguna cautela, la afluencia de personas o la densidad del tráfico. Sin embargo, el Dictamen señala que la realización de esta maniobra en autopistas o autovías implicará siempre una imprudencia grave, así como en vías interurbanas o urbanas a gran velocidad o con riesgo de atropello de personas. Si se efectúa con las cautelas adecuadas (de un modo lento y/o señalizado), pero sin cerciorarse del peligro que se pudiera ocasionar a terceros, se optará por la imprudencia menos grave. Por último, la atípica imprudencia leve quedaría reservada para casos que son fruto del despiste o de una momentánea distracción.

4. Comportamientos ante señales de stop y semáforos en rojo. Se insta también a efectuar una ponderación circunstancial de cada caso. No obstante, al ser las normas que regulan estas cuestiones claras y objetivas, que tienen que ver con lugares que de por sí son peligrosos, será difícil apreciar la imprudencia leve. Se considerará la imprudencia grave cuando la contravención de estas normas se produzca a gran velocidad, sin detenerse o sin adoptar ninguna medida de precaución; y menos grave cuando no se vaya a gran velocidad, haya detención aunque tardía por error de cálculo o cuando no hay detención ante un semáforo que se ve en ámbar pero que se rebasa ya en fase roja. Similares apreciaciones se efectúan con respecto a la señal de ceda el paso, aunque menos exigentes, ya que esta señal no obliga a detener el vehículo. Por ello, y aunque no se diga expresamente, se deja abierta la posibilidad de que con esta señal se aprecie la imprudencia leve.

5. Preferencias de paso. En caso de incorporaciones a la vía desde el arcén o desde el estacionamiento de una vía pública la imprudencia será grave, si se efectúan sin cerciorase del estado de la circulación, y leve si son producto de despistes o desatenciones momentáneas. En cuanto a cambios de dirección o de sentido a la izquierda, invadiendo el carril contrario, que puedan comprometer la circulación, se tenderá a apreciar la imprudencia grave, salvo que se hayan tomado algunas cautelas o comprobaciones, lo que implicará apreciar la menos grave. En los cambios de carril hacia la derecha, o de un mal uso de los carriles en la glorieta, la imprudencia será menos grave o leve, según el caso.

6. Alumbrado u otras condiciones técnicas del vehículo. El Dictamen no establece una catalogación precisa de qué tipo de infracciones de esta índole deben orientarse hacia un tipo de imprudencia $u$ otro. Solo recoge circunstancias a tener en cuenta. En relación 
al alumbrado aconseja atender a si se omite el alumbrado o si éste es insuficiente, y a si la conducta se produce por la noche, en túneles o con circunstancias ambientales adversas con poca visibilidad. En el caso de conducción con vehículos sin las condiciones técnicas adecuadas insta a atender a la entidad del incumplimiento, a si los órganos o elementos afectados del vehículo son esenciales para una conducción segura, y a la relación causal en la producción del resultado, así como su grado de previsibilidad.

7. Distracciones. Se atenderá a su entidad. Si son absolutas, la imprudencia será grave. Si son momentáneas o aisladas, la imprudencia será menos grave o leve. No obstante, se deberá tener en cuenta el carácter profesional del conductor, respecto de quien la valoración será más exigente, ya que se le pedirá un mayor grado de atención y concentración.

8. Estados de cansancio, fatiga o sueño. Si se comete la infracción muy grave del art. 77.i) LSV de incumplimiento en más del 50\% de los tiempos de conducción o descanso, será indiciaria de imprudencia grave, mientras que en los demás casos en los que la infracción no sea significativa por su tiempo, se apreciará imprudencia menos grave o leve. No obstante, si estos estados de «menor relevancia» se dan en conductores profesionales la imprudencia será grave.

9. Conductas con presencia de sujetos pasivos vulnerables. La normativa sobre seguridad vial recoge más exigentes e intensos deberes de control y cuidado en el desarrollo de la conducción cuando ésta se aproxima a sujetos especialmente vulnerables, como niños, personas con discapacidad, ancianos, peatones o ciclistas (así, por ejemplo, los arts. 13.1, 25 y 25 LSV), o transcurre en lugares en los que sea más previsiblemente su presencia (colegios, residencias de ancianos, etc.). Se establecen especiales previsiones de preferencia de paso, adelantamiento, velocidad permitida, etc. Se parte de que la vulneración de estos especiales deberes de precaución será constitutiva de imprudencia grave, sin perjuicio de que se pueda efectuar otra gradación de la imprudencia (menos grave o leve) en caso de que la norma de cuidado sea de menor relevancia, o concurran conductas imprudentes de la propia víctima.

\section{Conclusiones}

La introducción de la imprudencia menos grave en el Código penal por la LO 1/2015, de 30 de marzo, cuyo castigo se prevé en los delitos de homicidio y lesiones, ha suscitado dudas en cuanto su definición, esto es, en cuanto a si constituye un nuevo concepto de imprudencia con perfiles propios o simplemente una nueva manera de llamar a la antigua impru- 
dencia leve, al venir recogida ahora en los delitos leves y no en las faltas, debido a la derogación de estas últimas y la reubicación de algunas de ellas entre los delitos.

El Preámbulo de la referida Ley indica que «se estima oportuno reconducir las actuales faltas de homicidio y lesiones por imprudencia leve hacia la vía jurisdiccional civil». Con el término «reconducir» se viene a indicar que algo que antes era penal ahora lo es civil. Continúa indicando que la Ley penal recoge tras la reforma una modulación de la imprudencia entre grave y menos grave, que según el Preámbulo dará lugar a una mejor graduación de la responsabilidad penal en función de la conducta merecedora de reproche que "permitirá reconocer supuestos (por tanto, no todos, solo algunos) de imprudencia leve que deben quedar fuera del Código Penal». De estas palabras, y del hecho de que la imprudencia grave no haya sufrido modificación significativa, gozando del mismo ámbito de aplicación que hasta ahora, se ha de concluir que la imprudencia menos grave abarca los casos más graves de la antigua imprudencia leve, esto es, aquellos que no «deben» ser «reconducidos» fuera del Código penal, precisamente por albergar unos niveles mínimos de gravedad. Apoya esta consideración que se hayan aumentado considerablemente las penas de los delitos leves en los que se castiga ahora la nueva imprudencia menos grave. El homicidio por imprudencia leve se castigaba con multa de 1 a 2 meses y ahora, cometido por imprudencia menos grave, con multa de 3 a 18 meses. Las lesiones por imprudencia leve se sancionaban con multa de 10 a 30 días y ahora con multa de 3 meses a 1 año. Este importante aumento de pena solo puede corresponderse con la exigencia de un nivel mayor de gravedad a la nueva categoría de imprudencia, con el tope marcado por la gravedad de la imprudencia grave que no sufre modificación en cuanto a su regulación y castigo. Sin embargo, la doctrina y jurisprudencia sobre la cuestión refleja una absoluta falta de uniformidad a este respecto. Se defienden posiciones de todo tipo: la aquí expuesta, que la imprudencia menos grave abarca los casos menos graves de la antigua grave, unos y otros, o que viene a ser la misma imprudencia que la leve, solo que con otra terminología debido al hecho de que ahora sea castigada como delito y no como falta.

Las razones materiales del cambio, condicionadas por la efectiva eliminación de las faltas por LO 1/2015, y la inclusión de algunas como delitos leves, se centran en el principio de intervención mínima, que determina que en la esfera penal deban incardinarse supuestos graves de imprudencia, «reconduciendo otro tipo de conductas culposas a la vía civil... a la que habrá de acudir quien pretenda exigir responsabilidad por culpa de tal entidad». Así se expresa el citado Preámbulo de la Ley reformadora, y lo mismo parece requerir el Dictamen 2/2016, que se analiza en este trabajo, al señalar que la nueva imprudencia menos grave «es distinta de la anterior imprudencia leve... y de mayor cercanía a la grave, exigiendo la vulneración de deberes relevantes de cuidado", esto es, una vulneración de cierta significación de deberes de cuidado, más allá que la 
simple infracción de estos, pero sin llegar a los niveles requeridos tradicionalmente a la grave — que, como se ha dicho, no ha sido modificada-, quedando la leve, para infracciones del deber de cuidado sin significación (los meros despistes, descuidos o distracciones momentáneas) o de deberes de cuidado de insuficiente entidad. Estas palabras apoyan la conceptualización aquí defendida de la imprudencia menos grave.

Por otro lado, alguna doctrina atribuye a la nueva regulación otra función material relacionada con la praxis judicial. Y es que venía apreciándose que con la previsión de las dos imprudencias grave/leve la mayor parte de las muertes y lesiones por imprudencia en el ámbito del tráfico rodado eran consideradas como faltas. Y ello era así por las elevadas penas con las que se castigaba la primera en relación con la segunda, aunque se tratase de conductas imprudentes de relativa gravedad generadoras de importantes consecuencias. También, por no existir una imprudencia específica, con nombre y apellidos, en el ámbito civil, que generaba la tendencia a enjuiciar como falta conductas que carecían de una mínima relevancia penal, sin olvidar que los implicados preferían en todo caso la vía penal con el fin de obtener el informe médico forense de cara a cuantificar las lesiones producidas, aunque después la sentencia fuese desestimatoria. En un momento posterior, en un nuevo proceso civil, se buscaría las indemnizaciones deseadas por la compañía de seguros con el empleo de dicho informe. Por tanto, se castigaban como faltas tanto comportamientos graves que merecían la consideración de delito como comportamientos que merecían ser relegados al ámbito civil ${ }^{90}$.

Pero, esta práctica judicial, ¿se puede corregir con la novedosa triple estructuración de la imprudencia como grave/menos grave/leve? Creo que en parte sí. Por abajo, al no existir antes de 2015 en el ámbito civil una categoría de imprudencia con denominación específica, que debería de adjetivarse de un modo más leve que lo leve, es cierto que existía una, al menos ligera, tendencia a enjuiciar por vía penal la mayor parte de casos de imprudencia, como primera opción, aunque el art. 1902 CC admitiese ya expresamente el castigo de conductas imprudentes ${ }^{91}$. Con la reforma, con el envío ahora expreso y claro de una específica imprudencia, adjetivada de leve, al ámbito civil, se clarifica la existencia de ese espacio en dicho ámbito para el enjuiciamiento de comportamientos imprudentes. Y ello quizá sirva para evitar la referida tendencia a emplear el Derecho penal ante cualquier caso de esta naturaleza, incluso para levísimas desviaciones del riesgo permitido. Por arriba, la imprudencia grave no varía de contenido, pero el hecho de que los delitos por imprudencia menos grave reciban una pena bastante más grave que antes consigue que casos de cierta gravedad reciban una pena más proporcionada a su gravedad

90 Vid. Daunis Rodríguez, A., «La imprudencia», cit., pp. 35 y 38; y De Vicente MartíNEZ, R., «La reforma», cit., p. 51.

91 Como así indica, Lanzarote Martínez, P.A., «El nuevo», cit., p. 1738. 
que antes. La reforma podría servir para variar en algo la citada tendencia jurisprudencial de reenvío de casos graves al segundo escalón de la imprudencia, al recibir en este último una respuesta penal más equilibra$\mathrm{da}^{92}$. Es cierto que la tendencia es difícil de corregir ya que la diferencia de penas entre la imprudencia grave y menos grave sigue siendo aún importante. La primera se castiga con prisión y la segunda con multa. Además, la falta de ejecutividad real de la pena de prisión en condenas por delitos imprudentes puede hacer que los tribunales sigan restringiendo la clasificación de grave a casos de excepcional gravedad ${ }^{93}$, por tanto, a continuar con la tendencia descrita. También cabría acercar las imprudencias con la eliminación de la pena de prisión de la grave, dado que en todo caso se está ante acontecimientos no queridos por el autor, y aplicar junto a la multa penas aún más graves de inhabilitación especial.

Pero que la nueva regulación pueda servir en parte para corregir esta denunciada práctica judicial, o que haya sido diseñada para ello, no es suficiente para limitar la reforma a esta potencialidad y estimar que la regulación de la imprudencia no ha cambiado con respecto a la anterior y que es solo terminológica, tal y como parece declarar el Dictamen 2/2016. Lo corrobora el referido aumento del castigo penal de la imprudencia menos grave con respecto a la derogada leve. Que con la nueva adjetivación quede ahora un espacio en el ámbito civil más claramente delimitado para casos de nula gravedad - los que antes eran injustamente enjuiciados en la vía penal y otros cuya remisión extrapenal era ya indubitada - no obvia la existencia de casos de imprudencia que sin ser graves, tanto antes como ahora, deban encajar en la vía penal. Y que sean sancionados ahora con penas mucho más graves evidencia una elevación del nivel de gravedad de la imprudencia para este nuevo escalón intermedio. De ahí que se concluya que, ante el hecho de que la imprudencia grave no haya cambiado, la nueva categoría de imprudencia abarque los casos más graves de la antigua imprudencia leve.

En cuanto a la valoración de esta nueva graduación de la imprudencia, alguna doctrina estima, y ha estimado, positiva la reconducción de las figuras de menor lesividad a la vía civil ${ }^{94}$. En el ámbito de la circulación vial, por ejemplo, se trata de imprudencias que son producto de leves despistes o distracciones en situaciones normales de conducción o que implican infracciones de deberes de cuidado de muy reducida entidad, aun a pesar de las fatales consecuencias. Estoy de acuerdo. En sentido general, la vía penal debe reservarse para imprudencias que presenten des-

92 De forma similar, Daunis RodríGuEZ, A., «La imprudencia», cit., p. 36.

93 Tamarit Sumalla, J.M., ·De las lesiones», cit., p. 119.

$94 \mathrm{Vid}$., los argumentos a favor de la despenalización de la imprudencia leve, aunque no de la creación de una nueva categoría de imprudencia, que habría de generar aún más confusión, de FeIJoó SÁNCHez, B., «Los límites político-criminales de la responsabilidad por imprudencia: la imprudencia leve como hecho punible», en Revista del Poder Judicial, n. ${ }^{\circ} 61,2001$, pp. 113 y ss. 
de la perspectiva de su desvalor de acción un mínimo de relevancia, por constituir algo más que esos leves descuidos o distracciones o, de tratarse de estos, que los vulnerados sean deberes de cuidado de muy especial significación ${ }^{95}$, respecto de los que las exigencias de atención y precaución sean mayores. Sin embargo, algún sector doctrinal es crítico con esta supresión de las faltas de homicidio y lesiones por imprudencia leve del Código que, como se sabe, lesionan los bienes jurídicos más fundamentales. Todavía más si se mantienen en él, como delitos leves, conductas con objeto de tutela de nula entidad - aunque sean dolosas- como el uso indebido de uniformes, trajes o condecoraciones o las infracciones contra la propiedad intelectual constitutivas del top manta, por poner algunos ejemplos ${ }^{96}$. De este modo, se generan ámbitos de despenalización en supuestos que destruyen el bien más fundamental, la vida de las personas, lo que implica una disminución de su protección ${ }^{97}$, y muestra una falta de interés por reparar los daños viarios ${ }^{98}$, al ser derivados a la jurisdicción civil y quedar todavía más sometidos a los designios de las compañías aseguradoras ${ }^{99}$. Para este sector, el deseo de evitar la tendencia a utilizar interesadamente la vía penal - para obtener un informe médico forenseno es razón suficiente para justificar la despenalización de conductas con tan relevante desvalor de resultado que, además, pueden producirse en otros ámbitos distintos de la circulación vial. Su envío a sede civil implica un importante empeoro de la tutela judicial efectiva al quedar privados de la intervención de un juez imparcial, de las facilidades probatorias del procedimiento penal y del apoyo del Ministerio Fiscal ${ }^{100}$. No obstante,

95 Muñoz Conde, F. / García Arán, M., Derecho, cit., p. 308; y SuÁrez-Mira Rodríguez, C., «Del homicidio», cit., p. 486.

96 Críticos con la despenalización del homicidio y lesiones por imprudencia leve, y su relegación al ámbito civil, DE Vicente MARTíneZ, R., "La reforma», cit., pp. 44-48; Díez RiPOllÉs, J.L., "Sucintas», cit., p. 51; FARAldo CABANA, P., «La despenalización», cit., p. 7; Fernández Hernández, A., «Supresión», cit., pp. 55-57; y FERnández Hernández, A. / Olloquiegui Sucunza, I., «Notas», cit., p. 72.

97 Vid. De Vicente Martínez, R., «La reforma», cit., p. 45; Morales Prats, F., «Artículo 142», cit., p. 70; y, se lo plantea, PeÑaranda Ramos, E., "Homicidio», en AAVV. Memento práctico. Penal 2017. Francis Lefebvre, Madrid, 2016, p. 761.

98 Cfr. LANZARote Martínez, P.A., «El nuevo», cit., p. 1741.

99 Morales Prats, F., «Artículo 142», cit., p. 70.

100 Vid. Cugat Mauri, M., "Consecuencias», cit., p. 229; Faraldo Cabana, P., "La despenalización», cit., p. 7; o MANZANARES SAMANIEGo, J.L., La reforma, cit., pp. 39-42. Cierto es que la aprobación por el Consejo de Ministros de la exención del pago de tasas judiciales a las personas físicas, con el Real Decreto Ley 1/2015, de 27 de febrero, de mecanismos de segunda oportunidad, reducción de carga financiera y otras medidas de orden social, ha ayudado a hacer un poco menos costosa la utilización de la vía civil, ya que era otra de las críticas que se vertía sobre la derivación de estos casos a esta vía. Vid., sobre esta cuestión, Doval Pais, A., "Homicidios», cit., pp. 5-7. También la aprobación del Real Decreto 1148/2015, de 18 de diciembre, por el que se aprueba la realización de pericias a solicitud de particulares por los Institutos de Medicina Legal y Ciencias Forenses, en las reclamaciones extrajudiciales por hechos relativos a la circulación de vehículos a motor, que prevé la intervención extrajudicial del médico forense. Vid., sobre la cuestión, DE VICENTE MARTíNEZ, R., «La reforma», cit., pp. 47-48. 
aunque es cierto que se trata de conductas de elevado desvalor de resultado, también lo es que su desvalor de acción es nimio, para las que, a mi juicio, la utilización del Derecho penal deviene desproporcionado. Así lo debe requerir el principio de intervención mínima en su vertiente de fragmentariedad, y en este sentido se expresa el Dictamen 2/2016, cuando justifica y delimita los campos de acción de la imprudencia menos grave y leve. Esta rama del Derecho debe perseguir los comportamientos contra los bienes jurídicos más importantes pero que, además, sean los «más graves». Por tanto, para su castigo, no sólo se debe de tener en cuenta el bien jurídico afectado ${ }^{101}$. Además, si incluso las personas más diligentes pueden ser las que cometan «despistes» susceptibles de ser catalogados como imprudencias leves en el desarrollo de actividades comunes generadoras de peligros, ello evidencia que su castigo penal resulta completamente ineficaz desde una perspectiva de prevención general, sin que tampoco surta efectos preventivo-especiales significativos ${ }^{102}$. Por otro lado, para evitar aquella tendencia a usar el Derecho Penal, la clave está en instar al Ministerio Fiscal a que recupere su protagonismo como órgano promotor de la acción de la justicia y reconducir de oficio las infracciones imprudentes susceptibles de ser catalogadas como delito al cauce procesal propio ${ }^{103}$, con el fin de que cada conducta obtenga la respuesta penal adecuada a su gravedad, y evitar así que dicha labor se vea condicionada por el hecho de que el perjudicado se aparte de la acción penal al ver satisfechas sus expectativas de cobro, y perpetuar una generalizada sensación de que dichos ilícitos se pueden comprar a través del pago de las indemnizaciones ${ }^{104}$. Y quizá, también, la crítica aludida sea más apreciable si se construye a partir de una comparativa con otros casos, porque sí es cierto que no se han destipificado infracciones dolosas — como las descritas_- que son difícilmente justificables desde una perspectiva penal.

Pero más allá de este ejercicio de conceptualización de la imprudencia menos grave, y de su delimitación teórica con respecto a las otras categorías de imprudencia, el verdadero peligro de esta nueva triple graduación reside en su aplicación práctica. El esfuerzo delimitador de los campos de acción de cada categoría de imprudencia, como el

101 Vid. Feijoó SÁnchez, B., «Los límites», cit., pp. 108-109.

102 Vid. FeiJoó SÁnchez, B., «Los límites», cit., pp. 136-142; y Silva Sánchez, J., «Despenalización de las imprudencias leves», en InDret, n. ${ }^{\circ} 4$, 2009, p. 1. El primer autor también argumenta que el hecho de que la persecución de la imprudencia leve fuere a instancia de parte, esto es, que el ejercicio del ius puniendi se dejase en manos del particular, demostraba que no se trataba de perturbaciones que precisasen la intervención del Derecho Penal, y que, por tanto, hay otras posibles soluciones a ellas en otras ramas del ordenamiento; vid., mismo autor y obra, pp. 120-135.

103 Cfr. Doval PaIs, A., «Homicidios», cit., p. 12.

104 Caballero Gea, J-A., Delitos contra la seguridad vial. Código penal y Derecho procesal penal. Síntesis y ordenación de la doctrina de los Tribunales y Fiscalía General del Estado. Dykinson, Madrid, 2008, pp. 185-187. 
realizado con dedicación por el Dictamen 2/2016 que aquí se analiza, se ve abocado a una respuesta sometida a tantos juicios valorativos que deviene tremendamente discrecional. Y si ya antes el margen de discrecionalidad era alto ahora es mucho mayor, ya que las posibilidades de catalogación pasan de dos a tres. Los criterios de valoración de la gravedad de la imprudencia que da el Dictamen resultan por sí mismos lógicos y razonables. Eso es innegable. Pero las respuestas valorativas que ofrece para cada criterio no son definitivas, sino al contrario, susceptibles de interpretación y valoración. Así, por ejemplo, en atención a los deberes de prevención infringidos, si son básicos la imprudencia será grave pero si no lo son podrá ser menos grave o leve, sin establecer pauta para derivarlo hacia una u otra. Lo mismo sucede en atención a la desaprobación jurídica administrativa de la conducta. Si ésta es considerada infracción grave o muy grave la imprudencia será grave, pero si la infracción es leve, la imprudencia podrá ser menos grave o leve. E incluso a la hora de atender a la gravedad del riesgo generado se insta a valorar criterios difíciles de precisar en el caso concreto como el grado de captación del riesgo por el conductor, sus conocimientos particulares sobre el contenido concreto del riesgo, y sus condiciones psicofísicas relacionadas con el cansancio o el sueño. Y ello sin olvidar que el Dictamen insta a efectuar finalmente una valoración conjunta, combinada e interconectada de estos criterios generales, esto es, un juicio de conjunto, sin perjuicio de que, según el caso, puedan ser de objeto de valoración alternativa y no acumulativa, pudiendo enfatizarse la presencia de uno u otro si tienen especial presencia en el caso, e incluso atender a circunstancias concurrentes como las posibles infracciones de la víctima que obliguen efectuar una desvalorización de la gravedad $^{105}$. Por tanto, el sistema deviene enormemente incierto e inseguro, al ofrecer a los jueces muchas posibilidades interpretativas, a las que podrán dar más o menos énfasis, y con las que podrán ampararse sin excesivo problema para derivar el caso hacia una u otra vía jurisdiccional (incluso en orden a la idea preconcebida que pudieren tener), y justificar así un fallo condenatorio o absolutorio, de imprudencia grave, menos grave o leve. De hecho, incluso los criterios de valoración de la gravedad de la imprudencia que el Dictamen ofrece con respecto a prácticas concretas en la carretera (adelantamientos, preferencias de paso, excesos de velocidad), que en principio son más precisos, dejan también un margen amplio a la discrecionalidad. En alguna ocasión sirven para excluir una imprudencia pero no resuelven sobre las otras dos (como ocurre con respecto a preferencias de paso en los cambios de carril o en circulación en glorietas, en estados de cansancio o en distracciones momentáneas en la conducción). Con respecto a alguna práctica se considera que es «difícil» apreciar la imprudencia leve, pero ello no implica cerrar esa posibilidad sin que se diga cuándo pudiera

105 Sobre esta idea, Vid. DOVAL PAIS, A., «Homicidios», cit., p. 11. 
ser (así, con respecto a comportamientos ante señales de stop). Y en alguna ocasión, de una manera aún más genérica, se aconseja efectuar una "ponderación circunstancial de cada caso» (con respecto a comportamientos ante señales de stop y ceda el paso).

La variada jurisprudencia posterior a la reforma de 2015 muestra de un modo inequívoco esta discrecionalidad que se genera. Se encuentran ejemplos que siguen cualquiera de las posibilidades de definición de la imprudencia menos grave y de delimitación de su campo de acción, aunque muy pocas justifican sus posturas y ninguna se esfuerza por definir el nuevo concepto de imprudencia. Algunos absuelven en segunda instancia tras una condena por falta de lesiones, al señalar que la imprudencia leve ha sido despenalizada, pero sin entrar a valorar si los hechos enjuiciados pudiesen entrar en la nueva categoría o no ${ }^{106}$. O señalan que la imprudencia denunciada sólo podría considerarse leve de acuerdo con lo resuelto por la sentencia de instancia, pero sin justificarlo ${ }^{107}$. Son muestras de un nivel máximo de discrecionalidad que no se puede permitir bajo ningún concepto. Los jueces deben interpretar y delimitar los contornos de la nueva categoría de imprudencia menos grave, así como de la grave y nueva leve, reconduciendo las infracciones imprudentes al orden jurisdiccional que sea acorde con su gravedad. Para esa labor, las pautas y criterios recogidos en el Dictamen 2/2016, aun a pesar del carácter interpretable o valorativo de no pocas de ellas, son de gran utilidad. Deben ser objeto de utilización comprometida en la justificación de los fallos sobre la materia.

Para concluir, dos críticas más concretas a la regulación de la imprudencia.

En primer lugar, no se entiende por qué el art. $152 \mathrm{CP}$-que regula las lesiones imprudentes- recoge dos criterios para la graduación de la pena dentro del marco disponible, pero solo con respecto a la imprudencia grave, en su apartado primero. Se insta a atender al riesgo creado y al resultado producido. Estos criterios deben de operar también para la graduación de la pena de los tipos de imprudencia menos grave ${ }^{108}, \mathrm{y}$ aunque en la práctica así será, no se comprende su previsión expresa únicamente para la primera. Parece un olvido del legislador.

En segundo lugar, y en este caso se trata de una crítica de mayor importancia, la reforma deja fuera del Código penal las lesiones por imprudencia menos grave con resultados que no alcancen la gravedad de las lesiones de los arts. 149 y $150 \mathrm{CP}$, lo que abre un amplio margen a la vía civil para el enjuiciamiento de lesiones por aquella

\footnotetext{
106 SAP de Palma de Mallorca 6/2017, de 25 de enero.

107 SAP de Madrid 212/2016, de 9 de mayo.

108 Cfr. LanZarote MarTínez, P.A., «El nuevo», cit., p. 1743
} 
clase de imprudencia. No hay que olvidar que la mayoría de los accidentes de tráfico que ocasionan lesiones suponen el tipo básico del art. 147.1 $\mathrm{CP}^{109}$, cuya gravedad no es baladí, al requerir objetivamente para su curación, además de una primera asistencia facultativa, un tratamiento médico o quirúrgico. Se trata, pues, de comportamientos imprudentes con cierta gravedad (menos graves) susceptibles de originar consecuencias lesivas que, sin llegar a las de los arts. 149 y 150 $\mathrm{CP}$, son importantes, y que quedarán relegados a la vía civil ${ }^{110}$, la cual resulta más costosa, larga, sometida a los intereses de las aseguradoras y sin posibilidad de contar, a priori, con un dictamen pericial del forense ${ }^{111}$. Por ello, con respecto a estos casos, la decisión sí supone una reducción importante de la tutela de la vida y la salud ${ }^{112}$. La decisión de exigir los resultados de los arts. 149 y $150 \mathrm{CP}$ para el castigo de la imprudencia menos grave supone una sobrestimación del desvalor del resultado del tipo imprudente, cuando en esencia esta infracción se caracteriza por su desvalor de acción ${ }^{113}$. Además, contribuye a restar utilidad a la tarea de conceptualización de las clases de imprudencia en relación a su gravedad. El esfuerzo diferenciador de las imprudencias menos grave y leve, para saber cuál se sanciona penalmente y cuál queda relegada a la vía civil, se ve relativizado por el hecho de que el resultado producido sea uno u otro, por una cuestión de azar, ya que en ningún caso dicho resultado es abarcado por el conocimiento y voluntad del autor ${ }^{114}$. Lo relevante y característico de los comportamientos imprudentes es la infracción del deber de cuidado, y la respuesta

109 Cfr. LanZarote Martínez, P.A., «El nuevo», cit., p. 1741.

110 Sirva de ejemplo el AAP de Alicante 619/2016, de 15 de septiembre, que no castiga a un sujeto que, tras un accidente de tráfico, ocasiona por imprudencia menos grave a otro cefalea, un hombro doloroso y cervicalgia, al no ser constitutivas de las lesiones de los arts. 149 y $150 \mathrm{CP}$.

111 Lanzarote Martínez, P.A., «El nuevo», cit., p. 1741. Autores como Fernández HerNÁNDEZ, A., "Supresión», cit., p. 57; y RAMÓN RiBAS, E., «La responsabilidad», cit., p. 119, señalan que estas mayores dificultades de la vía civil pueden provocar que finalmente se acabe calificando como imprudencia menos grave lo que antes leve, dejando para este escalón supuestos todavía más excepcionales. Ello implicará un enorme e injustificado incremento punitivo de la imprudencia, al implicar la imposición de penas más elevadas - las de los nuevos delitos leves- a infracciones que siguen siendo las mismas, lo que supone una quiebra del principio de intervención mínima; así, LANZAROTE MARTínez, P.A., «El nuevo», cit., pp. 1741-1742.

112 Cfr. Doval Pais, A., «Homicidios», cit., pp. 88 y 11, aunque refiriéndose no solo a estos supuestos sino también a la decisión de destipificación de la imprudencia leve.

113 En este sentido Feijoó SÁNCHEZ, B., «Los límites», cit., p. 150, cuando señala que la producción de un resultado concreto no debe ser lo único que fundamente la punición de una infracción de un deber cuidado, pues implica dar excesivo valor al desvalor de resultado. De hecho, para el autor, defensor de la despenalización de la imprudencia leve, ésta constituía una infracción administrativa cualificada por el resultado, sin tener en cuenta el reproche del comportamiento individual.

114 Para FeIJoó SÁnchez, B., «Los límites», cit., pp. 143-144, no se puede hacer que se vea la pena como una lotería aplicable a quien tiene mala suerte, pues ello le resta legitimidad al Derecho Penal. 
penal debería ajustarse más a ella que al imprevisible resultado que se produzca. Por desgracia, la regulación de la imprudencia menos grave da excesiva relevancia a lo segundo.

\section{Bibliografía}

Caballero Gea, J-A., Delitos contra la seguridad vial. Código penal y Derecho procesal penal. Síntesis y ordenación de la doctrina de los Tribunales y Fiscalía General del Estado. Dykinson, Madrid, 2008.

Carbonell Mateu, J.C., "Homicidio y sus formas (I): homicidio», en González Cussac, J.L. (coord.), Derecho penal. Parte especial (5. ${ }^{a}$ edición). Tirant lo Blanch, Valencia, 2016, pp. 41-56.

Castro Corredoira, M. / Guinarte Cabada, G., «La reforma de los delitos de lesiones (arts. 157, 152 y 156)», en González CusSAC, J.L. (Dir.), Comentarios a la reforma del Código penal de 2015 (2. ${ }^{\mathrm{a}}$ edición). Tirant lo Blanch, Valencia, 2015, pp. 489-502.

Cerezo Mir, J., Curso de Derecho penal español. Parte General. Tomo II. Teoría jurídica del delito (6. . edición). Tecnos, Madrid, 2005.

Corcoy Bidasolo, M., «Homicidio y lesiones imprudentes cometidos con vehículos a motor o ciclomotor», en AA.VV. Derecho penal y seguridad vial. Estudios de Derecho Judicial, 114. CGPJ, Madrid, 2007, pp. 77-118.

Corcoy Bidasolo, M., El delito imprudente. Criterios de imputación del resultado. PPU. Barcelona, 1989.

Cugat Mauri, M., «Consecuencias penales de la supresión del Libro III», en Quintero Olivares, G. (Dir.), Comentario a la reforma penal de 2015. Thomson Aranzadi, Navarra, 2015, pp. 225-239.

Daunis RodríGuez, A., «La imprudencia menos grave», en InDret. Barcelona, 2018, pp. 1-49.

De Vicente Martínez, R., «La reforma penal de 2015 y su incidencia en los accidentes de circulación», en Revista Aranzadi Doctrinal. N. ${ }^{\circ} .5$. Mayo 2017, pp. 41-57.

De Vicente Martínez, R., «La reforma penal en curso en materia de siniestralidad vial», en AA.VV. Derecho penal y seguridad vial. Estudios de Derecho judicial, 114. CGPJ, Madrid, 2007, pp. 325-358.

Díez Ripollés, J.L., Derecho penal español. Parte General (4. a edición). Tirant lo Blanch. Valencia, 2016.

DíEz RIPOLLÉs, J.L., «Sucintas observaciones sobre algunas decisiones del Anteproyecto de reforma del Código penal de 2012», en ÁlVAREZ GARCíA, F.J. (Dir.), Estudio crítico sobre el anteproyecto de reforma penal de 2012. Tirant lo Blanch, Valencia, 2013, pp. 49-66. 
Doval PaIs, A., «Homicidios y lesiones por imprudencia: evolución, nuevo régimen y límites», en La ley penal: revista de derecho penal, procesal y penitenciario, n. ${ }^{\circ} 119,2016, \mathrm{pp} .1-24$.

EsteBAN, R., «El delito imprudente», en AA.VV. La imprudencia. Cuadernos de Derecho judicial. CGPJ, Madrid, 2006, pp. 51-68.

FARALDO CABANA, P., «La despenalización de las faltas: entre la agravación de las penas y el aumento de la represión administrativa», en Indret. Revista para el análisis del Derecho, n. ${ }^{\circ}$, Barcelona, 2014, pp. 1-32.

FeiJoó SÁnchez, B., «Los límites político-criminales de la responsabilidad por imprudencia: la imprudencia leve como hecho punible», en $R e$ vista del Poder Judicial, n. ${ }^{\circ}$ 61, 2001, pp. 105-164.

FERNÁNDEZ HERnÁNDEZ, A., «Supresión de las faltas y creación de los delitos leves», en GonzÁlez Cussac, J.L. (Dir.), Comentarios a la reforma del Código penal de 2015 (2. ${ }^{a}$ edición). Tirant lo Blanch, Valencia, 2015, pp. 45-82.

Fernández Hernández, A. / Olloquiegui Sucunza, I., «Notas críticas sobre la conversión de las faltas en delitos en el Anteproyecto de Reforma de 2012», en Álvarez García, F.J. (Dir.), Estudio crítico sobre el anteproyecto de reforma penal de 2012. Tirant lo Blanch, Valencia, 2013, pp. 67-76.

Frías Martínez, E., "Artículo 142», en Roma ValdÉs, A. (Dir.), Código penal comentado. Bosch. Barcelona, 2015, p. 273, pp. 271-273.

GIL GIL, A., «Artículo 12», en Gómez Tomillo, M., Comentarios prácticos al Código penal. Tomo I. Parte General. Artículos 1-137. Aranzadi, Navarra, 2015, pp. 151-162.

GIL GIL, A., El delito imprudente. Fundamentos para la determinación de lo injusto imprudente en los delitos activos de resultado. Atelier, Barcelona, 2007.

GonZÁlez CussaC, J.L., "La reforma penal de los delitos contra la seguridad vial», en AA.VV. Derecho penal y seguridad vial. Estudios de Derecho judicial, n. ${ }^{\circ}$ 114. CGPJ, Madrid, 2007, pp. 275-324.

Hava García, E., «Responsabilidad penal por imprudencia en la celebración de grande eventos: un análisis de algunas cuestiones problemáticas en el caso Madrid Arena», en Indret, Barcelona, abril 2017, pp. 1-36.

Hava García, E., El tipo de injusto del delito imprudente. Un análisis de sus elementos orientado a la práctica. Rubinzal-Culzoni editores, Buenos Aires, 2012.

Hava García, E., La imprudencia inconsciente. Comares. Granada, 2002.

JaÉn Vallejo, M. / Perrino Pérez, A., La reforma penal de 2015 (Análisis de las principales reformas introducidas en el Código penal por las Leyes Orgánicas 1 y 2/2015, de 30 de marzo). Dykinson, Madrid, 2015. 
LanZarote Martínez, P.a., «El nuevo delito de imprudencia menos grave en la reforma del Código penal», Diario La Ley, n. ${ }^{\circ} 8600,8$ septiembre 2015, pp. 1736-1743.

LuZón PeÑa, D-M., Lecciones de Derecho Penal. Parte General (3. ${ }^{a}$ edición). Tirant lo Blanch, Valencia, 2016.

Magro Servet, V., «Esquema sobre determinación de accidentes de tráfico a deriva al orden jurisdiccional penal tras la despenalización de las faltas de tráfico», en La Ley, n. ${ }^{\circ} 8735,2016$, p. 8.

Magro Servet, V., «La derogación de las faltas del Código penal: nuevas vías para luchar contra la delincuencia menor», en La Ley, 2009/4, pp. 1861-1866.l.

Manzanares Samaniego, J.L., La reforma del Código penal de 2015. Conforme a las Leyes Orgánicas 1 y 2/2015, de 30 de marzo. La Ley. Madrid, 2015.

Martínez-Buján Pérez, C., Derecho penal económico y de la empresa. Parte General (5. ${ }^{a}$ edición). Tirant lo Blanch, Valencia, 2016.

Medrano Arangueren, A., "Accidentes de tráfico: vía penal o vía civil», en CEFLegal: revista práctica de Derecho. Comentarios y casos prácticos. N. ${ }^{\circ}$ 190, 2016, pp. 173-178.

Mir Puig, S., Derecho penal. Parte General (10. ${ }^{\mathrm{a}}$ edición). Reppertor, Barcelona, 2016.

Molina Fernández, F., «Dolo, imprudencia y error», en AAVV. Memento práctico. Penal 2017. Francis Lefebvre, Madrid, 2016, pp. 285-300.

Morales Prats, F., «Artículo 142», en Quintero Olivares, G. (Dir.), Comentarios a la parte especial del Derecho Penal (10 . edición). Aranzadi, Navarra, 2016, pp. 65-70.

Muñoz Cuesta, J. / Ruiz De Erenchun Arteche, E., Cuestiones prácticas sobre la reforma penal de 2015. Aranzadi, Navarra, 2015.

MuÑoz RuIz, J., «Delitos contra la vida y la integridad física», en MORILLAS CUEVA, L. (Dir.), Estudios sobre el Código penal reformado (Leyes Orgánicas 1/2015 y 2/2015). Dykinson, Madrid, 2015.

Orts Berenguer, E. / González Cussac, J.L., Compendio de Derecho Penal. Parte General (6. ${ }^{a}$ edición). Tirant lo Blanch, Valencia, 2016.

Peñaranda Ramos, E., "Homicidio», en AAVV. Memento práctico. Penal 2017. Francis Lefebvre, Madrid, 2016, pp. 745-768.

Pérez Del Valle, C., La imprudencia en el Derecho penal. El tipo subjetivo del delito imprudente. Atelier, Barcelona, 2012.

Pla I Simón, S., «Protocolos de actuación y problemática de la actuación policial en materia de delitos contra la seguridad del tráfico», en Mir Puig, S. / Corcoy Bidasolo, M., Seguridad vial y Derecho penal. 
Análisis de la LO 15/2007, que modifica el Código penal en materia de Seguridad vial. Tirant lo Blanch, Valencia, 2008, pp. 345-350.

Quintero Olivares, G., Parte General del Derecho Penal. Adaptada al programa de ingreso en las carreras judicial y fiscal. Aranzadi, Navarra, 2015.

RAMÓN RiBAS, E., «La responsabilidad personal por impago de multa», en Quintero Olivares, G. (Dir.), Comentario a la reforma penal de 2015. Thomsom Aranzadi, Navarra, 2015, pp. 115-123.

Ramos TaPia, I., "Delito de acción: la tipicidad (III)», en Zugaldía EsPINAR, J.M., Lecciones de Derecho Penal. Parte General (3. ${ }^{a}$ edición). Tirant lo Blanch, Valencia, 2016, pp. 121-135.

Rando Casermeiro, P., La distinción entre el Derecho penal y el Derecho administrativo sancionador. Un análisis de política jurídica. Tirant lo Blanch, Valencia, 2010.

Romeo Casabona, C.M., "El homicidio y sus formas», en Romeo CasaboNA, C.M., Derecho Penal. Parte especial. Conforme a las Leyes Orgánicas 1 y 2/2015, de 30 de marzo. Granada 2016, pp. 1-53.

Roxin, C., Derecho penal. Parte General. Tomo I. Fundamentos. La estructura de la teoría del delito. Civitas, 2006.

Santos Martínez, A.M., «La "desjudicialización” de las faltas», en La Ley, 2011/4, pp. 1387-1391.

Silva SÁnchez, J., "Despenalización de las imprudencias leves», en InDret, n. ${ }^{\circ}$ 4, 2009, pp. 1-2.

SuÁrez-Mira Rodríguez, C., "Del homicidio y sus formas (arts. 138 y ss.)», en González Cussac, J.L. (Dir.), Comentarios a la reforma del Código penal de 2015 (2. ${ }^{\text {a }}$ edición). Tirant lo Blanch, Valencia, 2015, pp. 467-488.

Tamarit Sumalla, J.M., "De las lesiones», en Quintero Olivares, G. (Dir.), Comentarios a la parte especial del Derecho Penal (10 . edición). Aranzadi, Navarra, 2016, pp. 97-142.

Terradillos Basoco, J.M. ${ }^{\mathrm{a}}$, "Homicidio y sus formas», en Terradillos Basoco, J.M. ${ }^{a}$. (Coord.), Lecciones y materiales para el estudio del Derecho Penal. Tomo III. Derecho Penal. Parte Especial. Volumen I (2. edición). Iustel, Madrid, 2016, pp. 15-36.

ToRres FERnÁNDEZ, M. ${ }^{\mathrm{a}}$.E., «Reflexiones sobre algunos efectos administrativos del llamado "carnet por puntos» en las consecuencias penales de los delitos contra la seguridad vial», en Morillas Cueva, L. (Coord.), Delincuencia en materia de tráfico y seguridad vial (aspectos penales, civiles y procesales). Dykinson, Madrid, 2007, pp. 95-122.

Zárate Conde, A. / González Campo, E., Derecho penal. Parte General. La Ley. Madrid, 2015. 
